\title{
Isotopic constraints on heterogeneous sulfate production in Beijing haze
}

\author{
Pengzhen He ${ }^{1}$, Becky Alexander ${ }^{2}$, Lei Geng ${ }^{1}$, Xiyuan $\mathrm{Chi}^{1}$, Shidong Fan ${ }^{1}$, Haicong Zhan ${ }^{1}$, Hui Kang ${ }^{1}$, \\ Guangjie Zheng $^{3, a}$, Yafang Cheng ${ }^{3,4}$, Hang Su ${ }^{4,3}$, Cheng Liu ${ }^{1,5,6}$, and Zhouqing Xie ${ }^{1,5,6}$ \\ ${ }^{1}$ Anhui Province Key Laboratory of Polar Environment and Global Change, School of Earth and Space Sciences, \\ University of Science and Technology of China, Hefei, Anhui 230026, China \\ ${ }^{2}$ Department of Atmospheric Sciences, University of Washington, Seattle, WA 98195, USA \\ ${ }^{3}$ Multiphase Chemistry Department, Max Planck Institute for Chemistry, Mainz 55128, Germany \\ ${ }^{4}$ Jinan University, Institute for Environment and Climate Research, Guangzhou, Guangdong 511443, China \\ ${ }^{5}$ Key Lab of Environmental Optics and Technology, Anhui Institute of Optics and Fine Mechanics, \\ Chinese Academy of Sciences, Hefei, Anhui 230031, China \\ ${ }^{6}$ Center for Excellence in Urban Atmospheric Environment, Institute of Urban Environment, \\ Chinese Academy of Sciences, Xiamen, Fujian 361021, China \\ ${ }^{a}$ now at: Atmospheric Sciences Division, Brookhaven National Laboratory, Upton, NY 11973, USA
}

Correspondence: Zhouqing Xie (zqxie@ustc.edu.cn)

Received: 19 October 2017 - Discussion started: 6 November 2017

Revised: 21 March 2018 - Accepted: 24 March 2018 - Published: 23 April 2018

\begin{abstract}
Discerning mechanisms of sulfate formation during fine-particle pollution (referred to as haze hereafter) in Beijing is important for understanding the rapid evolution of haze and for developing cost-effective air pollution mitigation strategies. Here we present observations of the oxygen-17 excess of $\mathrm{PM}_{2.5}$ sulfate $\left(\Delta^{17} \mathrm{O}\left(\mathrm{SO}_{4}^{2-}\right)\right)$ collected in Beijing haze from October 2014 to January 2015 to constrain possible sulfate formation pathways. Throughout the sampling campaign, the 12-hourly averaged $\mathrm{PM}_{2.5}$ concentrations ranged from 16 to $323 \mu \mathrm{g} \mathrm{m}^{-3}$ with a mean of $(141 \pm 88(1 \sigma)) \mu^{-3} \mathrm{~m} \mathrm{~m}^{-3}$, with $\mathrm{SO}_{4}^{2-}$ representing 8-25\% of $\mathrm{PM}_{2.5}$ mass. The observed $\Delta^{17} \mathrm{O}\left(\mathrm{SO}_{4}^{2-}\right)$ varied from 0.1 to $1.6 \%$ with a mean of $(0.9 \pm 0.3) \%$ o. $\Delta^{17} \mathrm{O}\left(\mathrm{SO}_{4}^{2-}\right)$ increased with $\mathrm{PM}_{2.5}$ levels in October 2014 while the opposite trend was observed from November 2014 to January 2015. Our estimate suggested that in-cloud reactions dominated sulfate production on polluted days (PDs, $\mathrm{PM}_{2.5} \geq$ $75 \mathrm{~g} \mathrm{~m} \mathrm{~m}^{-3}$ ) of Case II in October 2014 due to the relatively high cloud liquid water content, with a fractional contribution of up to $68 \%$. During PDs of Cases I and III-V, heterogeneous sulfate production $\left(P_{\text {het }}\right)$ was estimated to contribute $41-54 \%$ to total sulfate formation with a mean of $(48 \pm 5) \%$. For the specific mechanisms of heterogeneous
\end{abstract}

oxidation of $\mathrm{SO}_{2}$, chemical reaction kinetics calculations suggested $\mathrm{S}(\mathrm{IV})\left(=\mathrm{SO}_{2} \cdot \mathrm{H}_{2} \mathrm{O}+\mathrm{HSO}_{3}^{-}+\mathrm{SO}_{3}^{2-}\right)$ oxidation by $\mathrm{H}_{2} \mathrm{O}_{2}$ in aerosol water accounted for $5-13 \%$ of $P_{\text {het }}$. The relative importance of heterogeneous sulfate production by other mechanisms was constrained by our observed $\Delta^{17} \mathrm{O}\left(\mathrm{SO}_{4}^{2-}\right)$. Heterogeneous sulfate production via $\mathrm{S}(\mathrm{IV})$ oxidation by $\mathrm{O}_{3}$ was estimated to contribute $21-22 \%$ of $P_{\text {het }}$ on average. Heterogeneous sulfate production pathways that result in zero- $\Delta^{17} \mathrm{O}\left(\mathrm{SO}_{4}^{2-}\right)$, such as $\mathrm{S}(\mathrm{IV})$ oxidation by $\mathrm{NO}_{2}$ in aerosol water and/or by $\mathrm{O}_{2}$ via a radical chain mechanism, contributed the remaining $66-73 \%$ of $P_{\text {het }}$. The assumption about the thermodynamic state of aerosols (stable or metastable) was found to significantly influence the calculated aerosol $\mathrm{pH}(7.6 \pm 0.1$ or $4.7 \pm 1.1$, respectively), and thus influence the relative importance of heterogeneous sulfate production via $\mathrm{S}(\mathrm{IV})$ oxidation by $\mathrm{NO}_{2}$ and by $\mathrm{O}_{2}$. Our local atmospheric conditions-based calculations suggest sulfate formation via $\mathrm{NO}_{2}$ oxidation can be the dominant pathway in aerosols at high-pH conditions calculated assuming stable state while $\mathrm{S}(\mathrm{IV})$ oxidation by $\mathrm{O}_{2}$ can be the dominant pathway providing that highly acidic aerosols $(\mathrm{pH} \leq 3)$ exist. Our local atmospheric-conditions-based calculations illustrate the utility of $\Delta^{17} \mathrm{O}\left(\mathrm{SO}_{4}^{2-}\right)$ for quantifying sulfate for- 
mation pathways, but this estimate may be further improved with future regional modeling work.

\section{Introduction}

Frequent occurrence of haze events in Beijing and throughout the North China Plain (NCP) during cold seasons is a health threat for around 400 million people living there. High concentrations of $\mathrm{PM}_{2.5}$ (particulate matter with an aerodynamic diameter less than $2.5 \mu \mathrm{m}$ ), of which the daily average can exceed $300 \mu \mathrm{g} \mathrm{m}^{-3}$ during severe haze (He et al., 2014; Jiang et al., 2015), contribute to cardiovascular morbidity and mortality (Brook et al., 2010; Cheng et al., 2013). As one of the major components of $\mathrm{PM}_{2.5}$, sulfate is of particular concern due to its high concentrations in haze days (Zheng et al., 2015b, a) and its key role in the climate system (Seinfeld and Pandis, 2006). Hourly sulfate concentrations can exceed $100 \mathrm{\mu g} \mathrm{m}^{-3}$ and account for up to one-quarter of $\mathrm{PM}_{2.5}$ mass during severe haze (Zheng et al., 2015a). However, due to the generally low solar radiation and cloud liquid water content during haze (Zheng et al., 2015a; Wang et al., 2014), conventional sulfate formation via $\mathrm{OH}$ oxidation in the gas phase and from aqueous-phase $\mathrm{SO}_{2}$ (referred to as $\mathrm{S}(\mathrm{IV})=\mathrm{SO}_{2} \cdot \mathrm{H}_{2} \mathrm{O}+\mathrm{HSO}_{3}^{-}+\mathrm{SO}_{3}^{2-}$ ) oxidation by $\mathrm{H}_{2} \mathrm{O}_{2}$ (McArdle and Hoffmann, 1983), $\mathrm{O}_{3}$ (Hoffmann and Calvert, 1985), and $\mathrm{O}_{2}$ via a radical chain mechanism initiated by transition metal ions (TMIs) in clouds (Ibusuki and Takeuchi, 1987; Alexander et al., 2009; Harris et al., 2013) cannot explain the observed high sulfate concentrations (Zheng et al., 2015a). To explain the observed high sulfate concentrations during haze in Beijing and the NCP, recent studies have suggested that heterogeneous reactions on/in aerosols/aerosol water are potentially important (He et al., 2014; Hung and Hoffmann, 2015; Cheng et al., 2016; Wang et al., 2016, 2014; Zheng et al., 2015a, b). In particular, Zheng et al. (2015a) largely improved the underestimate of modeled sulfate concentrations in 2013 Beijing haze by using a relative-humidity-dependent uptake coefficient $(\gamma)$ of $\mathrm{SO}_{2}$ on aerosols, without knowing the specific mechanisms of heterogeneous oxidation of $\mathrm{SO}_{2}$. Calculations by Guo et al. (2017) suggest heterogeneous oxidation of $\mathrm{SO}_{2}$ in Beijing may be dominated by $\mathrm{O}_{2}$ via a radical chain mechanism initiated by TMIs. Laboratory work has suggested $\mathrm{SO}_{2}$ oxidation by $\mathrm{O}_{3}$ on mineral dust is a significant pathway for sulfate production (Li et al., 2006), but its role in Beijing haze has not been determined. More recently, Hung and Hoffmann (2015) proposed that rapid $\mathrm{S}(\mathrm{IV})$ oxidation by $\mathrm{O}_{2}$ via a radical chain mechanism on acidic microdroplets $(\mathrm{pH} \leq 3)$ could be responsible for heterogeneous sulfate production in Beijing haze, while Cheng et al. (2016) suggested that S(IV) oxidation by $\mathrm{NO}_{2}$ (Lee and Schwartz, 1983; Clifton et al., 1988) in aerosol water could be important due to the high relative humidity and $\mathrm{NO}_{2}$ mole fraction during severe haze in the
Table 1. Sulfate isotope assumptions.

\begin{tabular}{lr}
$\begin{array}{l}\text { Sulfate formation } \\
\text { pathways }\end{array}$ & $\begin{array}{r}\Delta^{17} \mathrm{O}\left(\mathrm{SO}_{4}^{2-}\right) \\
(\% \circ)\end{array}$ \\
\hline $\mathrm{SO}_{2}+\mathrm{OH}$ & 0 \\
$\mathrm{~S}(\mathrm{IV})+\mathrm{H}_{2} \mathrm{O}_{2}$ & 0.7 \\
$\mathrm{~S}(\mathrm{IV})+\mathrm{O}_{3}$ & 6.5 \\
$\mathrm{~S}(\mathrm{IV})+\mathrm{NO}_{2}$ & 0 \\
$\mathrm{~S}(\mathrm{IV})+\mathrm{O}_{2}$ & 0 \\
Primary sulfate & 0 \\
\hline
\end{tabular}

NCP. Due to the strong $\mathrm{pH}$ dependence of $\mathrm{SO}_{2}$ oxidation and the large variability in model-calculated aerosol $\mathrm{pH}$ in Beijing haze (Cheng et al., 2016; Wang et al., 2016; Liu et al., 2017), the relative importance of heterogeneous $\mathrm{SO}_{2}$ oxidation is difficult to constrain.

The oxygen-17 excess $\left(\Delta^{17} \mathrm{O}\right)$ of sulfate, defined as $\Delta^{17} \mathrm{O}=\delta^{17} \mathrm{O}-0.52 \delta^{18} \mathrm{O}$, wherein $\delta=$ ( $\left.R_{\text {sample }} / R_{\text {reference }}-1\right)$ with $R$ representing the isotope ratios of ${ }^{17} \mathrm{O} /{ }^{16} \mathrm{O}$ or ${ }^{18} \mathrm{O} /{ }^{16} \mathrm{O}$ in the sample and the reference Vienna Standard Mean Ocean Water, respectively (Matsuhisa et al., 1978), is a useful tool for estimating the relative importance of different sulfate formation pathways because each oxidant transfers its $\Delta^{17} \mathrm{O}$ signature to the product (Table 1) through $\mathrm{SO}_{2}$ oxidation (Savarino et al., 2000). $\mathrm{SO}_{2}$ has $\Delta^{17} \mathrm{O}=0 \%$ due to the rapid isotopic exchange with abundant vapor water whose $\Delta^{17} \mathrm{O}$ is near $0 \%$ (Holt et al., 1981). S(IV) oxidation by $\mathrm{H}_{2} \mathrm{O}_{2}$ and $\mathrm{O}_{3}$ leads to $\Delta^{17} \mathrm{O}\left(\mathrm{SO}_{4}^{2-}\right)=0.7$ and $6.5 \%$, respectively, on the basis of $\Delta^{17} \mathrm{O}\left(\mathrm{H}_{2} \mathrm{O}_{2}\right)=1.4 \%$ (Savarino and Thiemens, 1999) and assuming $\Delta^{17} \mathrm{O}\left(\mathrm{O}_{3}\right)=26 \%$ (Vicars and Savarino, 2014; Ishino et al., 2017). Other sources of sulfate exhibit $\Delta^{17} \mathrm{O}\left(\mathrm{SO}_{4}^{2-}\right)$ at or near $0 \%$. Specifically, sulfate directly emitted from natural and anthropogenic sources or formed by $\mathrm{OH}$ and $\mathrm{O}_{2}$ oxidation has $\Delta^{17} \mathrm{O}\left(\mathrm{SO}_{4}^{2-}\right)$ values at or near 0\%o (Dubey et al., 1997; Luz and Barkan, 2005; Lee et al., 2002; Bao et al., 2000). Sulfate produced by $\mathrm{NO}_{2}$ oxidation is suggested to occur either via a radical chain mechanism (Shen and Rochelle, 1998), via oxygen-atom transfer from $\mathrm{OH}^{-}$(Clifton et al., 1988), or from $\mathrm{O}_{2}$ based on experimental results of $\mathrm{He}$ et al. (2014), resulting in $\Delta^{17} \mathrm{O}\left(\mathrm{SO}_{4}^{2-}\right)=0 \%$. Once formed, atmospheric sulfate does not undergo further isotopic exchange, and $\Delta^{17} \mathrm{O}\left(\mathrm{SO}_{4}^{2-}\right)$ will not be altered by mass-dependent processes such as deposition.

In this work, characteristics of $\mathrm{PM}_{2.5} \Delta^{17} \mathrm{O}\left(\mathrm{SO}_{4}^{2-}\right)$ during haze events from October 2014 to January 2015 in Beijing are reported, contributions of $\mathrm{O}_{3}$ and $\mathrm{H}_{2} \mathrm{O}_{2}$ oxidation in heterogeneous sulfate formation are quantified, and the roles of $\mathrm{NO}_{2}$ and $\mathrm{O}_{2}$ oxidation are explored. 


\section{Materials and methods}

\subsection{Sampling and atmospheric observations}

A high-volume air sampler (model TH-1000C II, Tianhong Instruments Co., Ltd., China) with a quartz microfiber filter (Whatman Inc., UK, pre-combusted at $450{ }^{\circ} \mathrm{C}$ for $4 \mathrm{~h}$ ) was used to collect $\mathrm{PM}_{2.5}$ samples at a flow rate of $1.05 \mathrm{~m}^{3} \mathrm{~min}^{-1}$ from October 2014 to January 2015. The collections lasted for $12 \mathrm{~h}(08: 00-20: 00$ or 20:00-08:00 LT) for each sample. The sample site is located on the rooftop of the First Teaching Building at the campus of the University of the Chinese Academy of Sciences $\left(40.41^{\circ} \mathrm{N}, 116.68^{\circ} \mathrm{E}\right.$, around $20 \mathrm{~m}$ from the ground) in Beijing, around $60 \mathrm{~km}$ northeast of downtown. Hourly $\mathrm{PM}_{2.5}$ concentration and $\mathrm{SO}_{2}$, $\mathrm{NO}_{2}$, and $\mathrm{O}_{3}$ mole fractions were observed at Huairou station $\left(40.33^{\circ} \mathrm{N}, 116.63^{\circ} \mathrm{E}\right)$ by the Beijing Municipal Environmental Monitoring Center, which is about $10 \mathrm{~km}$ from our aerosol sampling site. The mole fraction of atmospheric $\mathrm{H}_{2} \mathrm{O}_{2}$ was not observed in our campaign, but long-term observations from March to November in Beijing show a good correlation between $\mathrm{H}_{2} \mathrm{O}_{2}$ mole fraction and air temperature $\left(T\right.$ in $\left.{ }^{\circ} \mathrm{C}\right)$ according to $\left[\mathrm{H}_{2} \mathrm{O}_{2}\right] /\left(\mathrm{nmol} \mathrm{mol}^{-1}\right)=$ $0.1155 e^{0.0846 T /{ }^{\circ} \mathrm{C}}(\mathrm{Fu}, 2014)$. In the present study, $\mathrm{H}_{2} \mathrm{O}_{2}$ mole fraction was estimated from our measured $T$ with the empirical equation above. Our calculated $\mathrm{H}_{2} \mathrm{O}_{2}$ mole fraction based on this formula in October and November 2014 is, respectively $(0.32 \pm 0.08)$ and $(0.17 \pm 0.04) \mathrm{nmol} \mathrm{mol}^{-1}$, comparable to the observed values of $(0.44 \pm 0.18)$ and $(0.38 \pm$ $0.11) \mathrm{nmol} \mathrm{mol}^{-1}$, respectively, in October and November 2013 (Fu, 2014). Meteorological data including temperature, pressure, and relative humidity were recorded by an automatic weather station (model MetPak with integrated wind sonic, Gill Instruments Limited, UK). Time reported in this paper is local time $(\mathrm{LT}=\mathrm{UTC}+8)$.

\subsection{Measurements of ions and isotope ratios}

The measurements of ions were conducted in Anhui Province Key Laboratory of Polar Environment and Global Change in the University of Science and Technology of China. A detailed description of the method for chemical analysis of $\mathrm{NH}_{4}^{+}, \mathrm{K}^{+}, \mathrm{Ca}^{2+}, \mathrm{Na}^{+}, \mathrm{Mg}^{2+}, \mathrm{SO}_{4}^{2-}, \mathrm{NO}_{3}^{-}$, and $\mathrm{Cl}^{-}$can be found in the literature (Ye et al., 2015). Briefly, ions were extracted from a part $(2 \mathrm{~cm} \times 2 \mathrm{~cm})$ of each filter with $20 \mathrm{~mL}$ of Millipore water $(\geq 18 \mathrm{M} \Omega$ ) by sonication for $80 \mathrm{~min}$ in an ice water bath. Insoluble substances in the extract were filtered with $0.45 \mu \mathrm{m}$ filters before analysis. The $\mathrm{pH}$ of filtrates was measured by an ion activity meter (model PXS-215, Shanghai INESA Scientific Instrument Co., Ltd., China). And the ion concentrations were analyzed using a Dionex ICS-2100 ion chromatograph system (Thermo Fisher Scientific Inc., USA). Typical analytical precision of our instrument is better than $10 \%$ RSD (relative standard deviation) for all ions (Chen et al., 2016). The preparation and measurements of
$\Delta^{17} \mathrm{O}\left(\mathrm{SO}_{4}^{2-}\right)$ were conducted in the stable isotope laboratory (IsoLab) (https://isolab.ess.washington.edu/isolab/, last access: 12 December 2017) at the University of Washington, USA. A detailed description of the method can be found in the literature (Savarino et al., 2001; Geng et al., 2013; Chen et al., 2016; Alexander et al., 2012). Briefly, $\mathrm{PM}_{2.5}$ sample filters were dissolved in Millipore water $(\geq 18 \mathrm{M} \Omega)$ and the insoluble substances were filtered. Prepacked ion capture cartridges (Alltech Maxi-Clean IC-RP SPE) were used for the first step of removal of organics. Cations in the samples were replaced with sodium using a cation exchange resin and $30 \% \mathrm{H}_{2} \mathrm{O}_{2}$ solution was added as the second step of removal of organics. Excess $\mathrm{H}_{2} \mathrm{O}_{2}$ was removed via evaporation and $\mathrm{SO}_{4}^{2-}$ was separated from other anions (e.g., $\mathrm{NO}_{3}^{-}$) by ion chromatography. After ion separation, $\mathrm{SO}_{4}^{2-}$ was converted to $\mathrm{Ag}_{2} \mathrm{SO}_{4}$, dried, and then pyrolyzed at $1000^{\circ} \mathrm{C}$ in an elemental analyzer to form $\mathrm{Ag}(\mathrm{s}), \mathrm{SO}_{2}(\mathrm{~g})$, and $\mathrm{O}_{2}(\mathrm{~g})$. The produced gases were carried by $\mathrm{He}$ gas to pass through a liquid nitrogen trap to remove $\mathrm{SO}_{2}$, and then a gas chromatographer to further purify the $\mathrm{O}_{2}$ gas, which was finally moved to a mass spectrometer (Thermo Scientific MAT 253). Masses of 32,33 and 34 of $\mathrm{O}_{2}$ were measured to determine $\delta^{17} \mathrm{O}$ and $\delta^{18} \mathrm{O}$ and then $\Delta^{17} \mathrm{O}$ was calculated. The typical amount of $\mathrm{O}_{2}$ for each run is $0.4-0.8 \mu \mathrm{mol}$. The precision of $\Delta^{17} \mathrm{O}$ measurements in our method is $\pm 0.3 \%$ o based on replicate analysis of standards, which is consistent with previous studies (Alexander et al., 2005; Sofen et al., 2014; Chen et al., 2016). To quantify the uncertainty in each sample, 30 samples were measured in triplicate, two samples in quadruplicate, and two samples in duplicate depending on the limitation of sample size. In total, 10 filters sampled on non-polluted days (NPDs, $\mathrm{PM}_{2.5}<75 \mu \mathrm{g} \mathrm{m}^{-3}$ ) and 24 filters sampled on polluted days (PDs, $\mathrm{PM}_{2.5} \geq 75 \mu \mathrm{g} \mathrm{m}^{-3}$ ) were analyzed.

\subsection{Estimate of the overall rate of heterogeneous sulfate production}

Heterogeneous sulfate production $\left(P_{\text {het }}\right)$ is commonly parameterized in models according to Eq. (1) (Jacob, 2000; Zheng et al., 2015a):

$$
P_{\text {het }}=\frac{3600 \mathrm{sh}^{-1} \cdot 96 \mathrm{~g} \mathrm{~mol}^{-1} \cdot p}{R T}\left(\frac{R_{\mathrm{p}}}{D_{\mathrm{g}}}+\frac{4}{\nu \gamma}\right)^{-1} S_{\mathrm{p}}\left[\mathrm{SO}_{2}(\mathrm{~g})\right],
$$

where $P_{\text {het }}$ is in units of $\mu \mathrm{g} \mathrm{m}^{-3} \mathrm{~h}^{-1}, 3600 \mathrm{~s} \mathrm{~h}^{-1}$ is a time conversion factor, $96 \mathrm{~g} \mathrm{~mol}^{-1}$ is the molar mass of $\mathrm{SO}_{4}^{2-}$, $p$ is atmospheric pressure in $\mathrm{kPa}, R$ is the gas constant (8.31 $\mathrm{Pa} \mathrm{m}^{3} \mathrm{~mol}^{-1} \mathrm{~K}^{-1}$ ), and $T$ is temperature in $\mathrm{K} . R_{\mathrm{p}}$ is the radius of aerosol particles $(\mathrm{m}), D_{\mathrm{g}}$ is the gas-phase molecular diffusion coefficient of $\mathrm{SO}_{2}\left(\mathrm{~m}^{2} \mathrm{~s}^{-1}\right), v$ is the mean molecular speed of $\mathrm{SO}_{2}(\mathrm{~g})\left(\mathrm{m} \mathrm{s}^{-1}\right), \gamma$ is the uptake coefficient of $\mathrm{SO}_{2}$ on aerosols with the unit of $1,\left[\mathrm{SO}_{2}(\mathrm{~g})\right]$ is the gas-phase mole fraction of $\mathrm{SO}_{2}\left(\mathrm{nmol} \mathrm{mol}^{-1}\right)$, and $S_{\mathrm{p}}$ is the aerosol surface area per unit volume of air $\left(\mathrm{m}^{2} \mathrm{~m}^{-3}\right)$. The typical tropospheric value of $D_{\mathrm{g}}$ and $v$ is $2 \times 10^{-5}$ and $300 \mathrm{~m}^{2} \mathrm{~s}^{-1}$, 
respectively (Jacob, 2000). Observations of $\mathrm{PM}_{2.5}$ mass concentrations $\left(c\left(\mathrm{PM}_{2.5}\right), \mu \mathrm{g} \mathrm{m}^{-3}\right)$ and $\mathrm{PM}_{2.5}$ mean radius (m) during Beijing haze roughly follow an empirical formula: $R_{\mathrm{p}} / \mathrm{m}=\left(0.254 c\left(\mathrm{PM}_{2.5}\right) /\left(\mu \mathrm{g} \mathrm{m}^{-3}\right)+10.259\right) \times 10^{-9}($ Guo et al., 2014). By using the volume and surface area formulas of a sphere and the mean density of particles $\rho=1.5 \times$ $10^{6} \mathrm{~g} \mathrm{~m}^{-3}$ (Guo et al., 2014), $S_{\mathrm{p}}$ can be estimated from Eq. (2). A relative humidity-dependent $\gamma\left(=(2-5) \times 10^{-5}\right.$, Eq. 3) derived from Zheng et al. (2015a) during 2013 Beijing haze was used. This range of $\gamma$ is also consistent with the estimated values of $\gamma$ from $(1.6 \pm 0.7) \times 10^{-5}$ to $(4.5 \pm$ $1.1) \times 10^{-5}$ by Wang et al. (2016).

$$
\begin{aligned}
& S_{\mathrm{p}}=\frac{c\left(\mathrm{PM}_{2.5}\right) \times 10^{-6} \mathrm{~g} \mathrm{gg}^{-1}}{4 / 3 \cdot \pi R_{\mathrm{p}}^{3} \cdot \rho} \cdot 4 \pi R_{\mathrm{p}}^{2}, \\
& \gamma=\left\{\begin{array}{l}
2 \times 10^{-5}, \Psi \leq 50 \% \\
2 \times 10^{-5}+\frac{5 \times 10^{-5}-2 \times 10^{-5}}{100-50 \%} \cdot(\Psi-50 \%), \\
50 \% \leq \Psi \leq 100 \%
\end{array}\right.
\end{aligned}
$$

where $\Psi$ refers to relative humidity with the unit of $\%$.

\subsection{Estimate of primary sulfate}

The primary sulfate, which is directly emitted into air, includes the sea salt source, terrigenous source, and anthropogenic source (Li et al., 2013; Faloona, 2009). The concentration of sea salt sulfate was calculated by using the observed concentrations of $\mathrm{Na}^{+}$and the mass ratio of $c\left(\mathrm{SO}_{4}^{2-}\right) / c\left(\mathrm{Na}^{+}\right)=0.252$ in seawater (Calhoun et al., 1991). The terrigenous sulfate was estimated using the observed concentrations of $\mathrm{Ca}^{2+}$ and the mass ratio of $c\left(\mathrm{SO}_{4}^{2-}\right) / c\left(\mathrm{Ca}^{2+}\right)=0.18$ in soil (Legrand et al., 1997), where $c\left(\mathrm{Ca}^{2+}\right) / c\left(\mathrm{Na}^{+}\right)=0.038$ in seawater was used to calculate the fraction of observed $\mathrm{Ca}^{2+}$ from soil (Legrand and Mayewski, 1997). The anthropogenic primary sulfate is estimated as $3 \%$ of anthropogenic $\mathrm{SO}_{2}$ emissions in models (Faloona, 2009; Alexander et al., 2009). Supposing all the observed mole fractions of $\mathrm{SO}_{2}$ and precursors of secondary sulfate are anthropogenic, we have $c$ (ap) $/ 96=0.03\left(c\left(\mathrm{SO}_{2}\right) / 64+c\right.$ (sas) / 96), where $c(\mathrm{sas})=c(\mathrm{tos})-c(\mathrm{ss})-c(\mathrm{ts})-c(\mathrm{ap})$ and $c(\mathrm{ap}), c(\mathrm{sas}), c(\mathrm{tos})$, $c(\mathrm{ss})$, and $c(\mathrm{ts})$ are the mass concentrations of anthropogenic primary sulfate (ap), secondary sulfate (sas), total sulfate (tos), sea salt sulfate (ss), and terrigenous sulfate (ts). The estimated concentration of total primary sulfate $\left(\mathrm{p}^{-} \mathrm{SO}_{4}^{2-}\right)$ is the sum of primary sulfate from all these sources.

\subsection{Estimate of sulfate production rate from $\mathrm{OH}$ oxidation in the gas phase}

The sulfate production rate from $\mathrm{OH}$ oxidation in the gas phase $\left(P_{\mathrm{SO}_{2}}+\mathrm{OH}\right)$ can be expressed as

$$
P_{\mathrm{SO}_{2}+\mathrm{OH}}=\frac{3600 \mathrm{sh}^{-1} \cdot 96 \mathrm{~g} \mathrm{~mol}^{-1} \cdot p \cdot R_{\mathrm{SO}_{2}+\mathrm{OH}}}{R T},
$$

where $P_{\mathrm{SO}_{2}+\mathrm{OH}}$ is in units of $\mu \mathrm{g} \mathrm{m}^{-3} \mathrm{~h}^{-1}$ and $3600 \mathrm{sh}^{-1}$, $96 \mathrm{~g} \mathrm{~mol}^{-1}, p, R$, and $T$ are the same as in Eq. (1). $R_{\mathrm{SO}_{2}+\mathrm{OH}}$ is the chemical reaction rate $\left(\mathrm{nmol} \mathrm{mol}^{-1} \mathrm{~s}^{-1}\right)$, calculated as shown in Tables S1 and S2 in the Supplement.

\subsection{Estimate of in-cloud sulfate production rate}

The main in-cloud sulfate formation pathways considered here include $\mathrm{S}\left(\mathrm{IV}\right.$ ) oxidation by $\mathrm{H}_{2} \mathrm{O}_{2}, \mathrm{O}_{3}, \mathrm{NO}_{2}$ (Wang et al., 2016), and $\mathrm{O}_{2}$ via a radical chain mechanism initiated by TMIs (Alexander et al., 2009). Their chemical reaction rate expressions $\left(R_{\mathrm{S}(\mathrm{IV})+\text { oxi }}\right)$ and rate constants $(k)$ are summarized in Table S3. The rate of in-cloud sulfate production by a certain oxidant $\left(P_{\text {cloud, }} \mathrm{S}(\mathrm{IV})+\right.$ oxi $)$ can be expressed as (Seinfeld and Pandis, 2006)

$P_{\text {cloud, } \mathrm{S}(\mathrm{IV})+\text { oxi }}=3600 \mathrm{~s} \mathrm{~h}^{-1} \cdot 96 \mathrm{~g} \mathrm{~mol}^{-1} \cdot R_{\mathrm{S}(\mathrm{IV})}+$ oxi $\cdot \frac{L_{\mathrm{c}}}{\rho_{\mathrm{w}}}$,

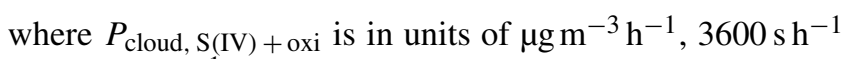
and $96 \mathrm{~g} \mathrm{~mol}^{-1}$ are the same as in Eq. (1), and $R_{\mathrm{S}(\mathrm{IV})+\text { oxi }}$ is in units of $\mathrm{M} \mathrm{s}^{-1}$. Cloud liquid water content $\left(L_{\mathrm{c}}\right.$, in unit of $\mathrm{m} \mathrm{m}^{-3}$ ) was derived from a global reanalysis, GEOS-FP (https://gmao.gsfc.nasa.gov/products/). $\rho_{\mathrm{w}}$ is the density of water $\left(1 \mathrm{~kg} \mathrm{~L}^{-1}\right)$. By summing up in-cloud $\mathrm{S}(\mathrm{IV})$ oxidation by $\mathrm{H}_{2} \mathrm{O}_{2}, \mathrm{O}_{3}, \mathrm{NO}_{2}$, and $\mathrm{O}_{2}$ initiated by TMIs, we can get the total rate of in-cloud sulfate production $\left(P_{\text {cloud }}\right)$.

\subsection{Isotopic constraints on sulfate formation pathways}

Since $\mathrm{S}(\mathrm{IV})$ oxidation by $\mathrm{O}_{3}$ and $\mathrm{H}_{2} \mathrm{O}_{2}$ are the sole sources of nonzero $\Delta^{17} \mathrm{O}\left(\mathrm{SO}_{4}^{2-}\right)$ (Table 1) (Savarino et al., 2000), the relative importance of different sulfate formation pathways can be calculated as follows (Alexander et al., 2012):

$$
\begin{aligned}
& \Delta^{17} \mathrm{O}_{\text {obs }}=\left(6.5 \% 0 \cdot f_{\mathrm{S}(\mathrm{IV})}+\mathrm{O}_{3}\right)+\left(0.7 \% o \cdot f_{\mathrm{S}(\mathrm{IV})+\mathrm{H}_{2} \mathrm{O}_{2}}\right) \\
& \quad+\left(0 \cdot f_{\text {zero }-\Delta^{17} \mathrm{O}}\right),
\end{aligned}
$$

where $f_{\mathrm{S}(\mathrm{IV})}+\mathrm{O}_{3}$ and $f_{\mathrm{S}(\mathrm{IV})}+\mathrm{H}_{2} \mathrm{O}_{2}$ are fractional contributions of $\mathrm{S}(\mathrm{IV})$ oxidation by $\mathrm{O}_{3}$ and $\mathrm{H}_{2} \mathrm{O}_{2}$ to the observed sulfate, respectively, and $f_{\text {zero }-\Delta^{17} \mathrm{O}}$ represents the fractional contribution of sulfate with zero- $-{ }^{17} \mathrm{O}$ processes such as primary sulfate, and secondary sulfate formed via $\mathrm{OH}$ oxidation, $\mathrm{NO}_{2}$ oxidation, and $\mathrm{O}_{2}$ oxidation. By using Eq. (6) and the definition $f_{\mathrm{S}(\mathrm{IV})}+\mathrm{O}_{3}+f_{\mathrm{S}(\mathrm{IV})}+\mathrm{H}_{2} \mathrm{O}_{2}+$ $f_{\text {zero- }-\Delta^{17} \mathrm{O}}=1$, we have $f_{\mathrm{S}(\mathrm{IV})}+\mathrm{O}_{3}=\left(\Delta^{17} \mathrm{O}_{\mathrm{obs}}-0.7 \%\right.$. $\left.f_{\mathrm{S}(\mathrm{IV})}+\mathrm{H}_{2} \mathrm{O}_{2}\right) / 6.5 \%$ and $f_{\text {zero }-\Delta{ }^{17} \mathrm{O}}=\left(6.5 \% o-\Delta^{17} \mathrm{O}_{\mathrm{obs}}-\right.$ $\left.5.8 \% 0 \cdot f_{\mathrm{S}(\mathrm{IV})}+\mathrm{H}_{2} \mathrm{O}_{2}\right) / 6.5 \%$. Since $f_{\mathrm{S}(\mathrm{IV})}+\mathrm{O}_{3}, f_{\mathrm{S}(\mathrm{IV})}+\mathrm{H}_{2} \mathrm{O}_{2}$, and $f_{\text {zero }-\Delta^{17} \mathrm{O}}$ should be in the range of 0 to 1 at the same time, $f_{\mathrm{S}(\mathrm{IV})}+\mathrm{H}_{2} \mathrm{O}_{2}$ is further limited to meet $f_{\mathrm{S}(\mathrm{IV})}+\mathrm{H}_{2} \mathrm{O}_{2}<$ $\min \left\{\Delta^{17} \mathrm{O}_{\text {obs }} / 0.7 \%\right.$, $\left(6.5 \% o-\Delta^{17} \mathrm{O}_{\text {obs }}\right) / 5.8 \%$ o $\}$. Therefore, the possible range of $f_{\mathrm{S}(\mathrm{IV})+\mathrm{O}_{3}}$ and $f_{\text {zero }-\Delta^{17} \mathrm{O}}$ can be obtained at different $f_{\mathrm{S}(\mathrm{IV})}+\mathrm{H}_{2} \mathrm{O}_{2}$ assumptions.

In addition, as sulfate with nonzero $\Delta^{17} \mathrm{O}\left(\mathrm{SO}_{4}^{2-}\right)$ is produced either via in-cloud reactions or via heterogeneous re- 
actions or both, Eq. (6) can also be written as follows:

$$
\begin{gathered}
\Delta{ }^{17} \mathrm{O}_{\text {obs }}=f_{\text {het }} \cdot \Delta^{17} \mathrm{O}_{\text {het }}+f_{\text {cloud }} \cdot \Delta \Delta^{17} \mathrm{O}_{\text {cloud }}+f_{\mathrm{SO}_{2}+\mathrm{OH}} \\
\Delta^{17} \mathrm{O}_{\mathrm{SO}_{2}+\mathrm{OH}}+f_{\mathrm{p}} \cdot \Delta{ }^{17} \mathrm{O}_{\mathrm{p}},
\end{gathered}
$$

where $f_{\text {het }}, f_{\text {cloud }}, f_{\mathrm{SO}_{2}+\mathrm{OH}}$, and $f_{\mathrm{p}}$ respectively represent the fractional contribution of heterogeneous sulfate production, in-cloud sulfate production, gas-phase sulfate production, and primary sulfate to the observed sulfate. $f_{\mathrm{p}}=c\left(\mathrm{p}^{-} \mathrm{SO}_{4}^{2-}\right) / c\left(\mathrm{SO}_{4}^{2-}\right)$, $f_{\text {het }}=\left\{P_{\text {het }} /\left(P_{\text {het }}+P_{\text {cloud }}+P_{\mathrm{SO}_{2}}+\mathrm{OH}\right)\right\} \cdot\left(1-f_{\mathrm{p}}\right)$, $f_{\text {cloud }}=\left\{P_{\text {cloud }} /\left(P_{\text {het }}+P_{\text {cloud }}+P_{\mathrm{SO}_{2}}+\mathrm{OH}\right)\right\} \cdot\left(1-f_{\mathrm{p}}\right)$ and $f_{\mathrm{SO}_{2}}+\mathrm{OH}=\left\{P_{\mathrm{SO}_{2}}+\mathrm{OH} /\left(P_{\text {het }}+P_{\text {cloud }}+P_{\mathrm{SO}_{2}+\mathrm{OH}}\right)\right\}$. $\left(1-f_{\mathrm{p}}\right) \cdot \Delta \Delta^{17} \mathrm{O}_{\text {het }}, \Delta^{17} \mathrm{O}_{\text {cloud }}, \Delta^{17} \mathrm{O}_{\mathrm{SO}_{2}+\mathrm{OH}}$, and $\Delta{ }^{17} \mathrm{O}_{\mathrm{p}}$ respectively represent $\Delta^{17} \mathrm{O}$ of corresponding sulfate produced via the pathways above. Both $\Delta^{17} \mathrm{O}_{\mathrm{SO}_{2}+\mathrm{OH}}$ and $\Delta{ }^{17} \mathrm{O}_{\mathrm{p}}$ are equal to $0 \%$ o. $\Delta^{17} \mathrm{O}_{\text {cloud }}$ can be calculated as shown in Eq. (8) as the lifetime of sulfate produced in clouds will not depend on the specific S(IV) oxidant.

$$
\begin{aligned}
& \Delta{ }^{17} \mathrm{O}_{\text {cloud }} \\
& =\frac{6.5 \% 0 \cdot P_{\text {cloud, }} \mathrm{S}(\mathrm{IV})+\mathrm{O}_{3}+0.7 \% \circ \cdot P_{\text {cloud, } \mathrm{S}(\mathrm{IV})+\mathrm{H}_{2} \mathrm{O}_{2}}}{P_{\text {cloud }}}
\end{aligned}
$$

\subsection{Calculation of aerosol liquid water content, aerosol $\mathrm{pH}$, and ionic strength $\left(I_{\mathrm{s}}\right)$}

Aerosol liquid water content, aerosol $\mathrm{pH}$, and $I_{\mathrm{s}}$ were calculated by the ISORROPIA II model, which is a thermodynamic equilibrium model for $\mathrm{NH}_{4}^{+}-\mathrm{K}^{+}-\mathrm{Ca}^{2+}-\mathrm{Na}^{+}-$ $\mathrm{Mg}^{2+}-\mathrm{SO}_{4}^{2-}-\mathrm{NO}_{3}^{-}-\mathrm{Cl}^{-}-\mathrm{H}_{2} \mathrm{O}$ aerosols (Fountoukis and Nenes, 2007). The ISORROPIA II model can solve forward problems in which $T$, relative humidity, and the concentrations of gas + aerosols are known (e.g., $\mathrm{NH}_{3}+\mathrm{NH}_{4}^{+}$), and reverse problems in which $T$, relative humidity, and the concentrations of aerosol (but not gas) species are known. We used the forward method to calculate aerosol liquid water content, aerosol $\mathrm{pH}$, and $I_{\mathrm{s}}$ as this method has been shown to best predict aerosol $\mathrm{pH}$ (Hennigan et al., 2015). The aerosol liquid water content, $\mathrm{pH}$, and $I_{\mathrm{S}}$ were first calculated in metastable mode (assuming that bulk aerosol solution is supersaturated), which is consistent with previous studies about Beijing haze (Liu et al., 2017; Guo et al., 2017). However, the work of Rood et al. (1989) in California, USA, suggested that not all aerosols are in a metastable state, even though the fractional occurrence of metastable aerosols increases with increasing relative humidity at urban sites (roughly following Eq. 9). We also calculated the aerosol liquid water content, $\mathrm{pH}$, and $I_{\mathrm{S}}$ assuming stable mode (assuming that bulk aerosols crystallize once saturation is exceeded), which is consistent with Wang et al. (2016). The input of observed inorganic ion concentrations and meteorological parameters are summarized in Table S4. Since gaseous $\mathrm{NH}_{3}$ was not measured in our campaign, we used the empirical equation $\left[\mathrm{NH}_{3}\right] /\left(\mathrm{nmol} \mathrm{mol}{ }^{-1}\right)$
$=0.34\left[\mathrm{NO}_{x}\right] /\left(\mathrm{nmol} \mathrm{mol}^{-1}\right)+0.63$, derived from observations of Meng et al. (2011) in Beijing winter, to estimate the $\mathrm{NH}_{3}$ mole fraction. We used $\mathrm{NO}_{2}$ mole fraction instead of $\mathrm{NO}_{x}$ as input due to the lack of $\mathrm{NO}_{x}$ observations in our study, which would give a lower end of $\mathrm{NH}_{3}$ mole fraction. Given the importance of aerosol liquid water content for reaction rates and the fact that ISORROPIA II underestimates aerosol liquid water content at low relative humidity (Bian et al., 2014), samples with relative humidity $<40 \%$ are excluded from analysis (Hennigan et al., 2015). This excludes 8 out of the total 34 samples (24\%), with six of them on NPDs. A total of four samples on NPDs and 22 samples on PDs were analyzed for aerosol liquid water content, aerosol $\mathrm{pH}$, and $I_{\mathrm{s}}$. Due to the fact that the predicted $I_{\mathrm{s}}$ is high $\left(I_{\mathrm{s}}>10 \mathrm{M}\right.$, Table S4), which suggests aerosol water is nonideal, the influence of $I_{\mathrm{S}}$ on reaction rate constants (Table S3) and effective Henry's law constants (Table S5) is taken into consideration when the influence is known.

$x$ (metastable)

$$
=\left\{\begin{array}{l}
0, \Psi<30 \% \\
-0.024(\Psi / \%)^{2}+4.18 \Psi / \%-89.13 \\
30 \% \leq \Psi \leq 80 \% \\
100 \%, 80 \%<\Psi \leq 100 \%
\end{array},\right.
$$

where $x$ (metastable) is the fraction of metastable aerosols to total aerosols in the unit of $\%$.

\subsection{Estimate of aqueous concentrations of trace species}

The aqueous concentrations of $\mathrm{SO}_{2}, \mathrm{O}_{3}, \mathrm{H}_{2} \mathrm{O}_{2}$, and $\mathrm{NO}_{2}$ were calculated as described in Table S5. The determination of in-cloud concentrations of TMIs (here only Fe(III) and Mn(II); Alexander et al., 2009) is described below.

The concentration of soluble Fe(III) follows Eqs. (10)(13) (Liu and Millero, 1999):

$$
\begin{aligned}
& \log _{10}\left([\mathrm{Fe}(\mathrm{III})] / c^{\ominus}\right)=\log _{10}\left(K_{\mathrm{Fe}(\mathrm{OH})_{3}}^{*}\left(c^{\ominus}\right)^{2}\right) \\
& \quad+3 \log _{10}\left(\left[\mathrm{H}^{+}\right] / c^{\ominus}\right)+\log _{10}\left(1+\beta_{1}^{*}\left(\left[\mathrm{H}^{+}\right] / c^{\ominus}\right)^{-1}\right. \\
& \left.\quad+\beta_{2}^{*}\left(\left[\mathrm{H}^{+}\right] / c^{\ominus}\right)^{-2}\right),
\end{aligned}
$$

where

$$
\begin{aligned}
& \log _{10}\left(K_{\mathrm{Fe}(\mathrm{OH})_{3}}^{*}\left(c^{\ominus}\right)^{2}\right)=-13.486-0.1856\left(I_{\mathrm{s}} / c^{\ominus}\right)^{0.5} \\
& \quad+0.3073\left(I_{\mathrm{S}} / c^{\ominus}\right)+5254 \mathrm{~K} / T \\
& \log _{10}\left(\beta_{1}^{*} /\left(c^{\ominus}\right)^{2}\right)=2.517-0.8885\left(I_{\mathrm{s}} / c^{\ominus}\right)^{0.5} \\
& \quad+0.2139\left(I_{\mathrm{S}} / c^{\ominus}\right)-1320 \mathrm{~K} / T \\
& \log _{10}\left(\beta_{2}^{*} /\left(c^{\ominus}\right)^{2}\right)=0.4511-0.3305\left(I_{\mathrm{s}} / c^{\ominus}\right)^{0.5} \\
& \quad-1996 \mathrm{~K} / T
\end{aligned}
$$

and $[\mathrm{Fe}(\mathrm{III})]$ is the aqueous concentration of $\mathrm{Fe}(\mathrm{III})$ in units of $\mathrm{M}, T$ is temperature in units of $\mathrm{K}$, and $I_{\mathrm{S}}$ is ionic strength 
in units of $\mathrm{M} . K_{\mathrm{Fe}(\mathrm{OH}) 3}^{*}$ is the solubility product constant of $\mathrm{Fe}(\mathrm{OH})_{3}$ in units of $\left(\mathrm{mol} \mathrm{L}^{-1}\right)^{-2}$, and $\beta_{1}^{*}$ and $\beta_{2}^{*}$ are respectively first-order and second-order cumulative hydrolysis constants of $\mathrm{Fe}^{3+}$ in units of $\left(\mathrm{mol} \mathrm{L}^{-1}\right)^{2}$.

Our calculation suggested in-cloud [Fe(III)] was in the range of 0.6 to $6.1 \mu \mathrm{M}$ with a mean of $(2.6 \pm 1.8) \mu \mathrm{M}$, which is similar to the observed values in the NCP (Guo et al., 2012; Shen et al., 2012). The concentration of soluble $\mathrm{Mn}(\mathrm{II})$ in cloud water was set to be $1 \mu \mathrm{M}$ in the present study, which is the general value observed in cloud water in the NCP (Guo et al., 2012; Shen et al., 2012).

\subsection{Estimate of sulfate production rate in aerosol water}

The reaction rate expressions, rate constants $(k)$, and influence of $I_{\mathrm{S}}$ on $k$ for sulfate production in aerosol water are summarized in Table S3. The overall rates for S(IV) oxidation in aerosol water depend not only on chemical reaction rates (Table S3) but also on mass transport limitations. A standard resistance model was used to estimate effects of mass transport following the work of Cheng et al. (2016):

$\frac{1}{R_{\mathrm{H}, \mathrm{S}(\mathrm{IV})}+\text { oxi }}=\frac{1}{R_{\mathrm{S}(\mathrm{IV})+\text { oxi }}}+\frac{1}{J_{\mathrm{aq}, \lim }}$,

where $R_{\mathrm{H}, \mathrm{S}(\mathrm{IV})}+$ oxi is the overall reaction rate for $\mathrm{S}(\mathrm{IV})$ oxidation by a certain oxidant (oxi) such as $\mathrm{O}_{3}, \mathrm{H}_{2} \mathrm{O}_{2}, \mathrm{NO}_{2}$, and $\mathrm{O}_{2}$ on acidic microdroplets $\left(\mathrm{M} \mathrm{s}^{-1}\right), R_{\mathrm{S}(\mathrm{IV})}+$ oxi is the chemical reaction rate $\left(\mathrm{M} \mathrm{s}^{-1}\right)$, and $J_{\mathrm{aq}}$, lim is the rate limited by mass transfer from the gas to the aqueous phase $\left(\mathrm{M} \mathrm{s}^{-1}\right)$. Due to the large decrease in the aqueous-phase reaction rate constant for TMI-initiated S(IV) oxidation by $\mathrm{O}_{2}$ with increasing $I_{\mathrm{S}}$ (Martin and Hill, 1967) and the high $I_{\mathrm{S}}$ of aerosols (Table S4), combined with the fact that the rate constant for the $\mathrm{S}(\mathrm{IV})+\mathrm{O}_{2}$ mechanism on acidic microdroplets proposed by Hung and Hoffman (2015) likely includes the effect of TMIs, we do not directly consider TMI-initiated S(IV) oxidation by $\mathrm{O}_{2}$ in aerosol water. $R_{\mathrm{S}(\mathrm{IV})}+$ oxi was calculated as described in Table S3. The limiting mass transfer $J_{\mathrm{aq}}$, lim was calculated using Eqs. (15) and (16).

$J_{\mathrm{aq}, \lim }=\min \left\{J_{\mathrm{aq}}\left(\mathrm{SO}_{2}\right), J_{\mathrm{aq}}(\mathrm{oxi})\right\}$,

$J_{\mathrm{aq}}(\mathrm{X})=k_{\mathrm{MT}}(\mathrm{X}) \cdot[\mathrm{X}(\mathrm{aq})]$,

where $X=\mathrm{SO}_{2}, \mathrm{O}_{3}, \mathrm{H}_{2} \mathrm{O}_{2}$, or $\mathrm{NO}_{2}$ and $k_{\mathrm{MT}}\left(\mathrm{s}^{-1}\right)$ is the mass transfer rate coefficient and was calculated as Eq. (17) (Cheng et al., 2016; Seinfeld and Pandis, 2006):

$k_{\mathrm{MT}}(X)=\left[\frac{R_{\mathrm{p}}^{2}}{3 D_{\mathrm{g}}}+\frac{4 R_{\mathrm{p}}}{3 \alpha v}\right]^{-1}$,

where $R_{\mathrm{p}}, D_{\mathrm{g}}$, and $v$ are the same as in Eq. (1). The $\alpha$ used in our calculation is 0.11 for $\mathrm{SO}_{2}, 0.23$ for $\mathrm{H}_{2} \mathrm{O}_{2}, 2.0 \times 10^{-3}$ for $\mathrm{O}_{3}$, and $2.0 \times 10^{-4}$ for $\mathrm{NO}_{2}$ (Seinfeld and Pandis, 2006; Jacob, 2000). The term on the left-hand side of Eq. (17) is the gas-phase diffusion limitation while the term on the righthand side of Eq. (17) is the interfacial mass transport limitation. $k_{\mathrm{MT}}$ was limited by interfacial mass transport in our study.

The rate of heterogeneous sulfate production by a certain oxidant $\left(P_{\text {het, }} \mathrm{S}(\mathrm{IV})+\right.$ oxi $)$ in aerosol water can be expressed as

$P_{\text {het, } \mathrm{S}(\mathrm{IV})}+$ oxi $=3600 \mathrm{sh}^{-1} \cdot 96 \mathrm{~g} \mathrm{~mol}^{-1} \cdot R_{\mathrm{H}, \mathrm{S}(\mathrm{IV})}+$ oxi $\cdot \frac{L_{\mathrm{a}}}{\rho_{\mathrm{W}}}$,

where $P_{\text {het, } \mathrm{S}(\mathrm{IV})}+$ oxi is in units of $\mu \mathrm{g} \mathrm{m}^{-3} \mathrm{~h}^{-1}$ and $3600 \mathrm{~s} \mathrm{~h}^{-1}$ and $96 \mathrm{~g} \mathrm{~mol}^{-1}$ are the same as in Eq. (1). $R_{\mathrm{H}, \mathrm{S}(\mathrm{IV})+\text { oxi is in }}$ units of $\mathrm{M} \mathrm{s}^{-1}, L_{\mathrm{a}}$ is aerosol liquid water content in units of $\mathrm{mg} \mathrm{m}^{-3}$, and $\rho_{\mathrm{w}}$ is the density of water $\left(1 \mathrm{~kg} \mathrm{~L}^{-1}\right)$.

\section{Results and discussion}

\subsection{Characteristics of haze events in Beijing}

Figure 1a shows the temporal evolution of concentrations of $\mathrm{PM}_{2.5}$ and $\mathrm{SO}_{4}^{2-}$ during our sampling period. The 12hourly averaged $\mathrm{PM}_{2.5}$ concentrations ranged from 16 to $323 \mu \mathrm{g} \mathrm{m}^{-3}$ with a mean of $(141 \pm 88(1 \sigma)) \mu \mathrm{g} \mathrm{m}^{-3}$. In comparison, the grade II of the Chinese national ambient air quality standard of daily $\mathrm{PM}_{2.5}$ is $75 \mu \mathrm{g} \mathrm{m}^{-3}$. The $\mathrm{SO}_{4}^{2-}$ concentrations varied from 1.5 to $56.4 \mu \mathrm{g} \mathrm{m}^{-3}$ with a mean of $(21.2 \pm 15.4) \mu \mathrm{g} \mathrm{m}^{-3}$. As shown in Fig. $1 \mathrm{a}, \mathrm{SO}_{4}^{2-}$ concentrations presented a similar temporal trend as $\mathrm{PM}_{2.5}$ concentrations, i.e., increased from a mean of $(3.9 \pm 1.8) \mu \mathrm{g} \mathrm{m}^{-3}$ on NPDs $\left(\mathrm{PM}_{2.5}<75 \mu \mathrm{g} \mathrm{m}^{-3}\right)$ to $(28.4 \pm 12.5) \mu \mathrm{g} \mathrm{m}^{-3}$ on PDs $\left(\mathrm{PM}_{2.5} \geq 75 \mu \mathrm{g} \mathrm{m}^{-3}\right)$. The fraction of $\mathrm{SO}_{4}^{2-}$ to $\mathrm{PM}_{2.5}$ mass concentration ranged from 8 to $25 \%$ and increased from a mean of $(11 \pm 2) \%$ on NPDs to $(15 \pm 5) \%$ on PDs. The sulfur oxidation ratio ( $\mathrm{SOR}$, which equals $\mathrm{SO}_{4}^{2-}$ molar concentration divided by the sum of $\mathrm{SO}_{4}^{2-}$ and $\mathrm{SO}_{2}$ molar concentration), a proxy for secondary sulfate formation (Sun et al., 2006), also increased rapidly with $\mathrm{PM}_{2.5}$ levels, from a mean of $0.12 \pm 0.04$ on NPDs to $0.41 \pm 0.17$ on PDs (Fig. 1b).

Observed $\Delta^{17} \mathrm{O}\left(\mathrm{SO}_{4}^{2-}\right)\left(\Delta^{17} \mathrm{O}_{\text {obs }}\right)$ ranged from 0.1 to $1.6 \%$ with a mean of $(0.9 \pm 0.3) \%$ o (Fig. 1b). The highest $\Delta^{17} \mathrm{O}_{\text {obs }}=1.6 \%$ occurred during PDs of Case II in October 2014 , while the lowest $\Delta^{17} \mathrm{O}_{\text {obs }}=0.1 \%$ occurred during PDs of Case IV in December 2014. $\Delta{ }^{17} \mathrm{O}_{\text {obs }}$ reported here is similar in magnitude to previous observations of $\Delta^{17} \mathrm{O}\left(\mathrm{SO}_{4}^{2-}\right)$ in aerosols and rainwater collected in China (Lin et al., 2017; Li et al., 2013) and other midlatitude sites (Table S6). The overall $\Delta^{17} \mathrm{O}_{\text {obs }}$ levels during our entire sampling time are similar for NPDs and PDs, being $(0.9 \pm 0.1)$ and $(0.9 \pm 0.4) \%$, respectively. However, the NPD-to-PD difference of $\Delta^{17} \mathrm{O}_{\mathrm{obs}}$ can be case dependent. For Case I and II in October 2014, $\Delta{ }^{17} \mathrm{O}_{\text {obs }}$ increased from NPDs to PDs, while the opposite trend was observed for Cases III to $\mathrm{V}$ in November 2014 to January 2015 (Fig. 1b). These $\Delta^{17} \mathrm{O}_{\mathrm{obs}}$ variations are generally similar to variability in mole frac- 


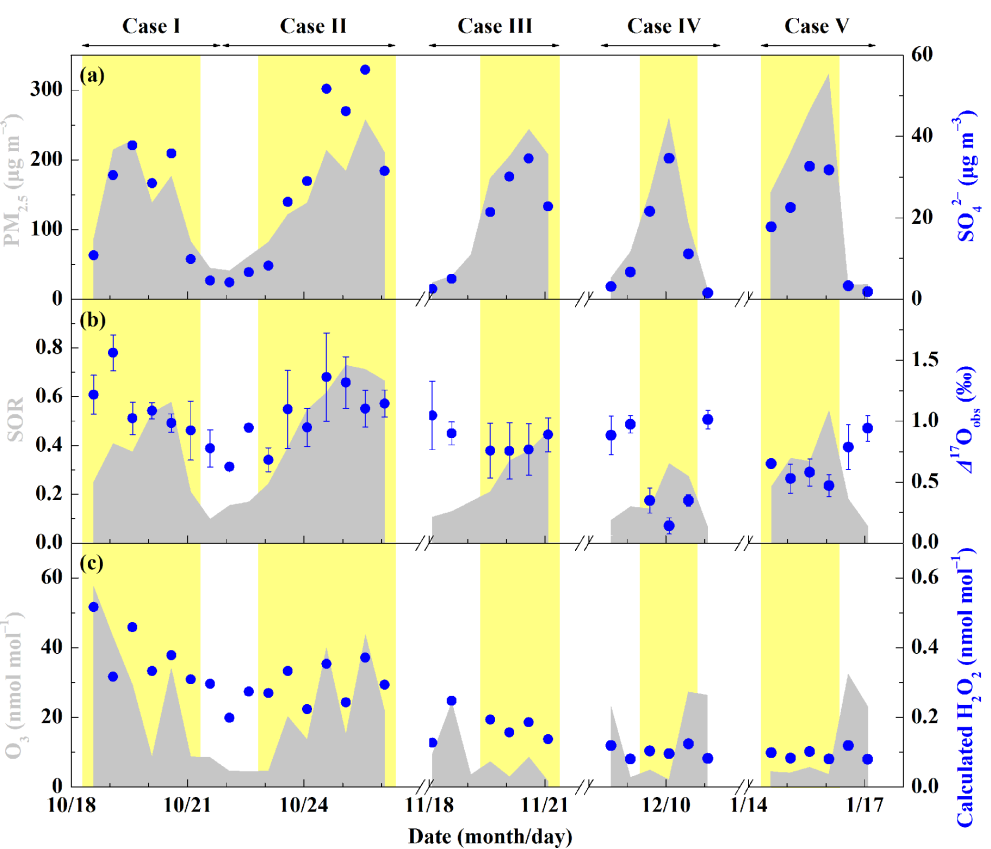

Figure 1. Characteristics of haze events in Beijing (October 2014-January 2015). (a) Temporal evolution of $\mathrm{PM}_{2.5}$ and $\mathrm{SO}_{4}^{2-}$ concentrations. (b) Temporal evolution of sulfur oxidation ratio ( $\mathrm{SOR}$, which equals $\mathrm{SO}_{4}^{2-}$ molar concentration divided by the sum of $\mathrm{SO}_{4}^{2-}$ and $\mathrm{SO}_{2}$ molar concentration) and observed $\Delta^{17} \mathrm{O}\left(\mathrm{SO}_{4}^{2-}\right)\left(\Delta^{17} \mathrm{O}_{\mathrm{obs}}\right)$. (c) Temporal evolution of observed $\mathrm{O}_{3}$ and calculated $\mathrm{H}_{2} \mathrm{O}_{2}$. The error bar of $\Delta{ }^{17} \mathrm{O}_{\mathrm{obs}}$ in (b) is $\pm 1 \sigma$ of replicate measurements $(n=2-4)$ of each sample. The light yellow shaded area indicates polluted days (PDs, $\mathrm{PM}_{2.5} \geq 75 \mu \mathrm{g} \mathrm{m}^{-3}$ ). Data used here are 12-hourly averaged values, corresponding with filter samples.

tions of observed $\mathrm{O}_{3}$ and calculated $\mathrm{H}_{2} \mathrm{O}_{2}$ (Fig. 1c), which is consistent with the fact that $\mathrm{O}_{3}$ and $\mathrm{H}_{2} \mathrm{O}_{2}$ are the sole sources of nonzero $\Delta^{17} \mathrm{O}\left(\mathrm{SO}_{4}^{2-}\right)$ (Table 1$)$.

\subsection{Direct estimate of sulfate formation pathways based on $\Delta{ }^{17} \mathbf{O}_{\text {obs }}$}

Figure 2 shows the calculated possible fractional contribu-

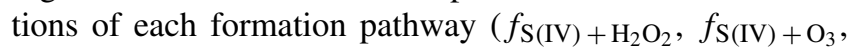
and $f_{\text {zero }-\Delta^{17} \mathrm{O}}$ ) for each sample using Eq. (6). On average, over all samples collected, $f_{\mathrm{S}(\mathrm{IV})}+\mathrm{O}_{3}=4-13 \%$, $f_{\mathrm{S}(\mathrm{IV})}+\mathrm{H}_{2} \mathrm{O}_{2}=0-88 \%$, and $f_{\text {zero }-\Delta^{17} \mathrm{O}}=8-87 \%$. For samples during PDs of Case IV in December 2014 with the three lowest $\Delta^{17} \mathrm{O}_{\text {obs }}$ values (Fig. 1b), $f_{\text {zero }-\Delta{ }^{17} \mathrm{O}}$ was in the range of 57-95, 86-98, and 57-95\%, corresponding to $f_{\mathrm{S}(\mathrm{IV})}+\mathrm{H}_{2} \mathrm{O}_{2}$ being in the range of $0-43,0-14$, and $0-43 \%$, respectively, which clearly suggests zero- $\Delta^{17} \mathrm{O}$ pathways dominated sulfate formation during PDs of Case IV. However, for other samples, the maximum possible $f_{\mathrm{S}(\mathrm{IV})}+\mathrm{H}_{2} \mathrm{O}_{2}$ ranged from 71 to $100 \%$ with a mean of $(93 \pm 7) \%$ while the maximum possible $f_{\text {zero }-\Delta{ }^{17} \mathrm{O}}$ was 75 to $92 \%$ with a mean of $(86 \pm 4) \%$, implying that sulfate formation during these sampling periods was dominated by $\mathrm{H}_{2} \mathrm{O}_{2}$ oxidation and/or zero- $\Delta{ }^{17} \mathrm{O}$ pathways.

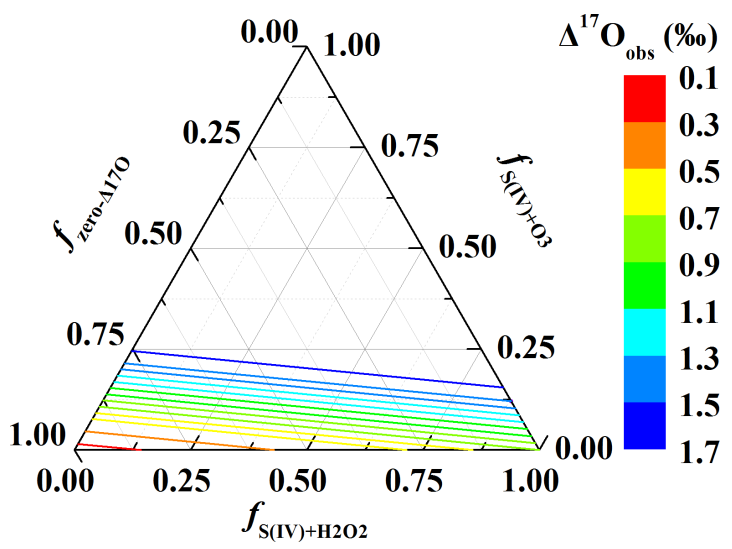

Figure 2. Ternary diagram of possible fractional contribution of different pathways to total sulfate production directly estimated from $\Delta^{17} \mathrm{O}_{\text {obs. }}$. The colored lines are contour lines of $\Delta{ }^{17} \mathrm{O}_{\mathrm{obs}}$, representing possible fractional contribution of sulfate formation via $\mathrm{O}_{3}\left(f_{\mathrm{S}(\mathrm{IV})}+\mathrm{O}_{3}\right)$ and $\mathrm{H}_{2} \mathrm{O}_{2}\left(f_{\mathrm{S}(\mathrm{IV})}+\mathrm{H}_{2} \mathrm{O}_{2}\right)$ oxidation or zero- $\Delta^{17} \mathrm{O}$ processes $\left(f_{\text {zero- }-\Delta{ }^{17} \mathrm{O}}\right)$ such as primary sulfate, secondary sulfate formed via $\mathrm{OH}$ oxidation, $\mathrm{NO}_{2}$ oxidation, and $\mathrm{O}_{2}$ oxidation. $f_{\mathrm{S}(\mathrm{IV})+\mathrm{H}_{2} \mathrm{O}_{2}}$ is in the range of 0 to $\min \left\{\Delta^{17} \mathrm{O}_{\text {obs }} / 0.7 \%\right.$ o, $\left.\left(6.5 \% o-\Delta^{17} \mathrm{O}_{\text {obs }}\right) / 5.8 \% o\right\}$, $f_{\mathrm{S}(\mathrm{IV})}+\mathrm{O}_{3}=\left(\Delta^{17} \mathrm{O}_{\mathrm{obs}}-0.7 \% \circ \times f_{\mathrm{S}(\mathrm{IV})}+\mathrm{H}_{2} \mathrm{O}_{2}\right) / 6.5 \%$, and $f_{\text {zero }-\Delta{ }^{17} \mathrm{O}}=\left(6.5 \% o-\Delta^{17} \mathrm{O}_{\text {obs }}-5.8 \% \circ \times f_{\mathrm{S}(\mathrm{IV})}+\mathrm{H}_{2} \mathrm{O}_{2}\right) / 6.5 \%$. See Eq. (6) and its caption in Sect. 2.7 for details. 

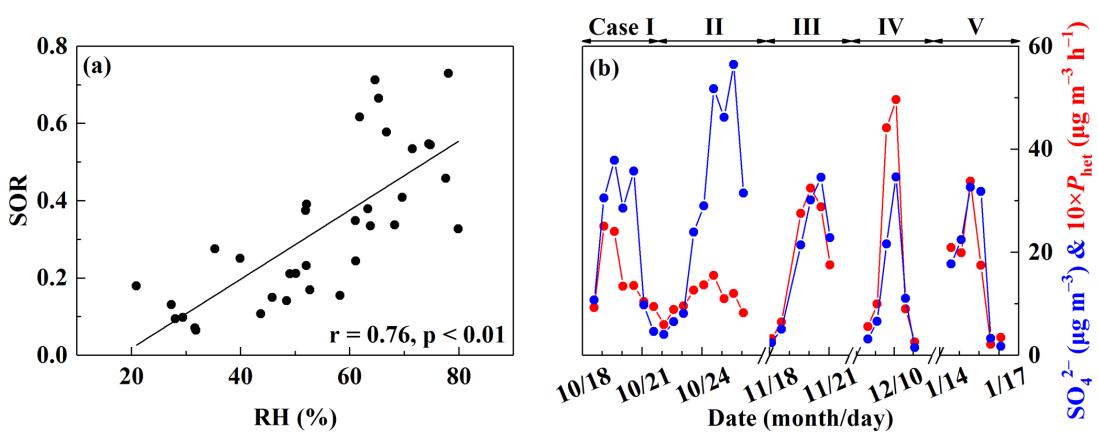

Figure 3. The relationship between relative humidity (RH) and SOR (a) and time series of overall heterogeneous sulfate production $\left(P_{\text {het }}\right)$ along with $\mathrm{SO}_{4}^{2-}$ concentrations (b). The black line in (a) is the linear least-squares fitting line.

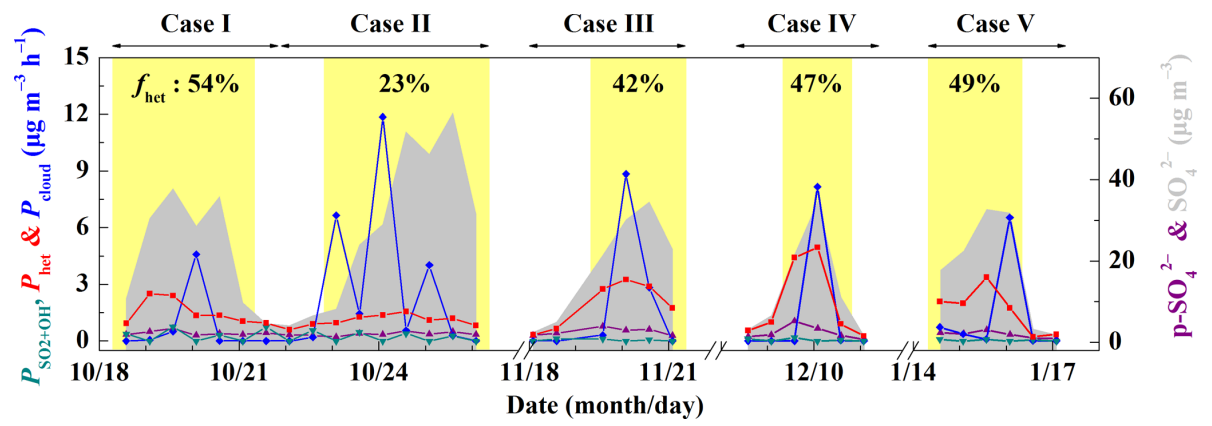

Figure 4. Estimate of different sulfate production pathways. Time series of estimated sulfate production rate via $\mathrm{OH}$ oxidation in the gas phase $\left(P_{\mathrm{SO}_{2}}+\mathrm{OH}\right)$, overall heterogeneous reactions on aerosols $\left(P_{\text {het }}\right)$ and in-cloud reactions $\left(P_{\text {cloud }}\right)$, and concentrations of primary sulfate $\left(\mathrm{p}-\mathrm{SO}_{4}^{2-}\right)$ and observed sulfate. $f_{\text {het }}$ represents the fraction of overall heterogeneous sulfate production to total sulfate production during PDs of each case. The light yellow shaded area indicates polluted days (PDs, $\mathrm{PM}_{2.5} \geq 75 \mu \mathrm{g} \mathrm{m}^{-3}$ ). Data used here are 12 -hourly averaged values, corresponding with filter samples.

Table 2. Estimated fractional contribution of different sulfate production pathways during Beijing haze.

\begin{tabular}{lrrrr}
\hline $\begin{array}{l}\text { PD of } \\
\text { case }\end{array}$ & $\begin{array}{r}f_{\mathrm{p}}{ }^{*} \\
(\%)\end{array}$ & $\begin{array}{r}f_{\text {het }} \\
(\%)\end{array}$ & $\begin{array}{r}f_{\text {cloud }} \\
(\%)\end{array}$ & $\begin{array}{r}f_{\mathrm{SO}_{2}+\mathrm{OH}} \\
(\%)\end{array}$ \\
\hline I & 9 & 54 & 29 & 8 \\
II & 6 & 23 & 68 & 3 \\
III & 11 & 41 & 47 & 1 \\
IV & 15 & 47 & 37 & 1 \\
V & 9 & 49 & 41 & 1 \\
\hline
\end{tabular}

$* f_{\mathrm{p}}, f_{\text {het }}, f_{\text {cloud }}$, and $f_{\mathrm{SO}_{2}}+\mathrm{OH}$ respectively represent fractional contribution from primary sulfate, heterogeneous reactions, in-cloud reactions, and the gas-phase pathway.

\subsection{Chemical kinetic calculations with the constraint of $\Delta{ }^{17} \mathbf{O}_{\text {obs }}$}

The good correlation between relative humidity and SOR in Fig. 3a $(r=0.76, p<0.01)$ suggests heterogeneous reactions played an important role in sulfate formation. Our local atmospheric-conditions-based calculations show that overall heterogeneous sulfate production $\left(P_{\text {het }}\right.$; see Sect. 2.3) presented similar trends to $\mathrm{SO}_{4}^{2-}$ concentrations except for
Case II (Fig. 3b) and increased from a mean of $(0.6 \pm$ $0.3) \mu \mathrm{g} \mathrm{m}^{-3} \mathrm{~h}^{-1}$ on NPDs to $(2.0 \pm 1.1) \mu \mathrm{g} \mathrm{m}^{-3} \mathrm{~h}^{-1}$ on PDs during our entire sampling period. In comparison, Cheng et al. (2016) reported that the missing sulfate production rate required explanation of the observed sulfate concentration being around $0.07 \mu \mathrm{g} \mathrm{m}^{-3} \mathrm{~h}^{-1}$ when $\mathrm{PM}_{2.5}<50 \mu \mathrm{g} \mathrm{m}^{-3}$ and around $4 \mu \mathrm{g} \mathrm{m}^{-3} \mathrm{~h}^{-1}$ when $\mathrm{PM}_{2.5}>400 \mu \mathrm{g} \mathrm{m}^{-3}$ during 2013 Beijing haze. We also calculated the contribution from primary sulfate and performed chemical kinetic calculations including $\mathrm{SO}_{2}$ oxidation by $\mathrm{OH}$ in the gas phase and in-cloud sulfate production (Fig. 4 and Table 2; see Sect. 2.4-2.6) to estimate the relative importance of heterogeneous sulfate production in our sampling period. Heterogeneous reactions were found to contribute $41-54 \%$ to total sulfate formation during PDs of Cases I and III-V, with a mean of $(48 \pm 5) \%$ (Fig. 4). This is consistent with Zheng et al. (2015a), who modeled that about half of the observed sulfate was from heterogeneous reactions during 2013 Beijing haze. In contrast, we found that during PDs of Case II in October 2014, heterogeneous sulfate production only accounted for $23 \%$ of total sulfate production while in-cloud sulfate production predominated total sulfate production with an estimated fraction of $68 \%$. The predominant role of in-cloud sulfate production 


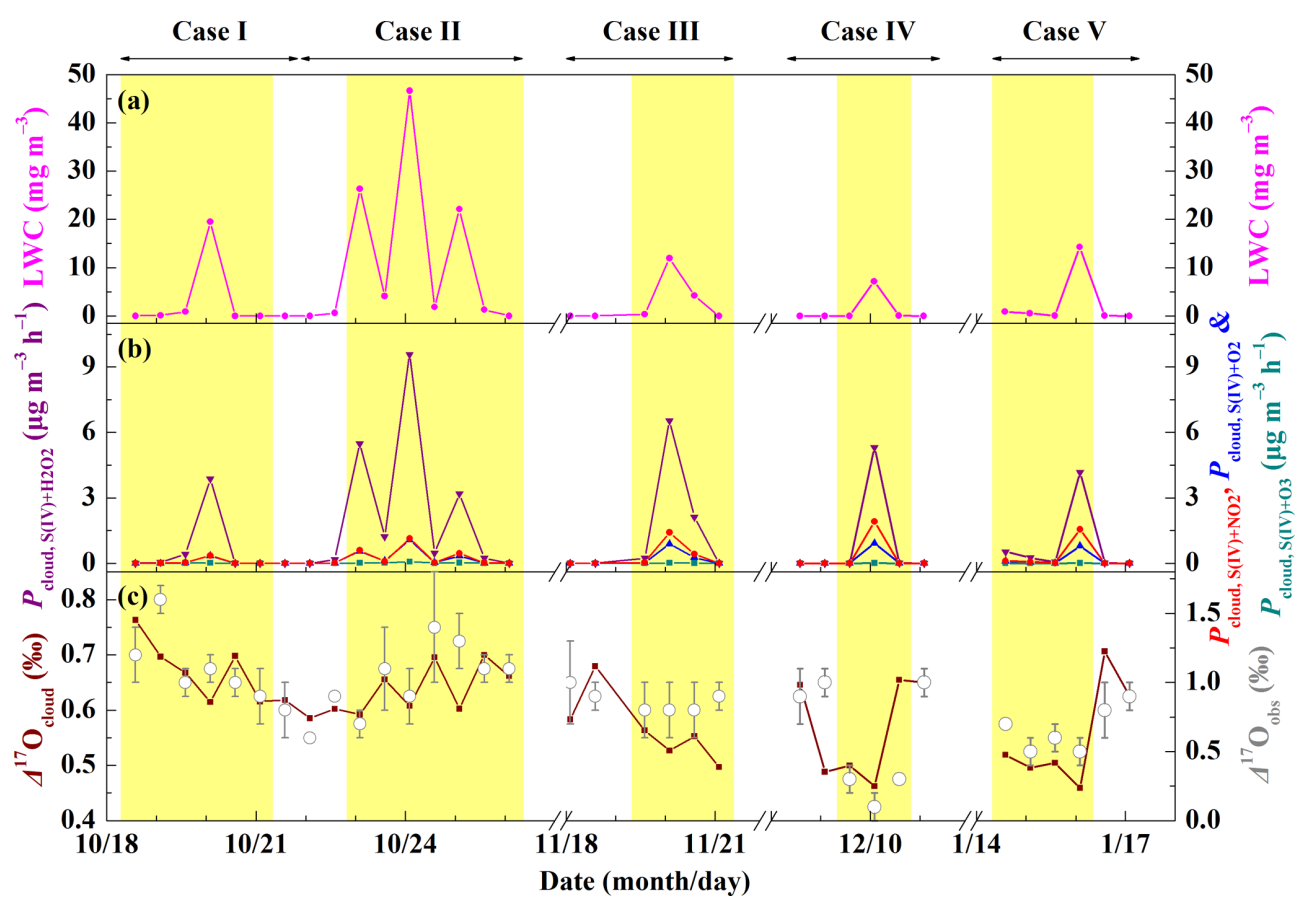

Figure 5. Temporal evolution of cloud liquid water content (LWC, a), in-cloud sulfate production rate via $\mathrm{S}(\mathrm{IV})$ oxidation by $\mathrm{H}_{2} \mathrm{O}_{2}$, $\mathrm{O}_{3}$, $\mathrm{NO}_{2}$, and $\mathrm{O}_{2}$ initiated by TMIs (denoted as $P_{\text {cloud, }} \mathrm{S}(\mathrm{IV})+\mathrm{H}_{2} \mathrm{O}_{2}, P_{\text {cloud, }} \mathrm{S}(\mathrm{IV})+\mathrm{O}_{3}, P_{\text {cloud, }} \mathrm{S}(\mathrm{IV})+\mathrm{NO}_{2}$, and $P_{\text {cloud, }} \mathrm{S}(\mathrm{IV})+\mathrm{O}_{2}$, respectively; b) and estimated $\Delta^{17} \mathrm{O}$ of sulfate produced in clouds $\left(\Delta^{17} \mathrm{O}_{\text {cloud }}, \mathbf{c}\right)$. The light yellow shaded area indicates polluted days $\left(\mathrm{PDs}, \mathrm{PM}_{2.5} \geq 75\right.$ $\mu \mathrm{g} \mathrm{m}^{-3}$ ). Data used here are 12-hourly averaged values, corresponding with filter samples.

on PDs of Case II was supported by the relatively high cloud liquid water content during this time period (Fig. 5a). Our local atmospheric-conditions-based calculations also suggest the in-cloud sulfate production was dominated by $\mathrm{H}_{2} \mathrm{O}_{2}$ oxidation throughout our sampling period (Fig. 5b), which is consistent with previous findings that $\mathrm{H}_{2} \mathrm{O}_{2}$ oxidation is the most important in-cloud sulfate production pathway globally (Alexander et al., 2012) and in the NCP (Shen et al., 2012). In addition, the $\Delta^{17} \mathrm{O}$ of sulfate produced in clouds $\left(\Delta^{17} \mathrm{O}_{\text {cloud }}\right)$ was estimated to range from 0.5 to $0.8 \%$ with a mean of $(0.6 \pm 0.1) \%$ o during our sampling period and showed similar variations as $\Delta^{17} \mathrm{O}_{\text {obs }}$ (Fig. 5c). The mean value of $\Delta^{17} \mathrm{O}_{\text {cloud }}$ calculated here is close to $\Delta^{17} \mathrm{O}\left(\mathrm{SO}_{4}^{2-}\right)$ in rainwater observed in central China $(0.53 \pm 0.19 \%$ ) (Li et al., 2013) and at Baton Rouge, USA $(0.62 \pm 0.32 \%$ ) (Jenkins and Bao, 2006). In addition, by using Eq. (7), the $\Delta^{17} \mathrm{O}$ of sulfate produced via heterogeneous reactions $\left(\Delta^{17} \mathrm{O}_{\text {het }}\right)$ was calculated to be respectively $1.8,3.1,1.4,0.1$, and $0.8 \%$ for PDs of Cases I-V. Since $\Delta^{17} \mathrm{O}\left(\mathrm{SO}_{4}^{2-}\right)$ produced via $\mathrm{H}_{2} \mathrm{O}_{2}$ oxidation is $0.7 \%$, smaller than $\Delta^{17} \mathrm{O}_{\text {het }}$ in Cases I-III and V, $\mathrm{O}_{3}$ oxidation must contribute to heterogeneous sulfate production.

To explore the specific mechanisms of heterogeneous oxidation of $\mathrm{SO}_{2}$, we calculated aerosol parameters such as aerosol liquid water content, $\mathrm{pH}$, and ionic strength $\left(I_{\mathrm{s}}\right)$ by using the ISORROPIA II thermodynamic model (Fountoukis and Nenes, 2007) (Fig. 6; see Sect. 2.8). It was found that the assumptions about aerosol thermodynamic state (salts crystallize once saturation is exceeded, termed as stable state or aerosol solution is supersaturated, termed as metastable state) significantly influence the calculated aerosol $\mathrm{pH}$ but have little impact on the calculated aerosol liquid water content and $I_{\mathrm{S}}$ (Fig. 6). Calculated aerosol liquid water content increased with $\mathrm{PM}_{2.5}$ concentrations, from $(5.3 \pm 7.4) \mu \mathrm{g} \mathrm{m}^{-3}$ on NPDs to $(63.5 \pm 54.6) \mu \mathrm{g} \mathrm{m}^{-3}$ on PDs when assuming a stable state and from $(9.6 \pm 6.0) \mu \mathrm{g} \mathrm{m}^{-3}$ on NPDs to $(84.2 \pm 49.2){\mu \mathrm{g} \mathrm{m}^{-3}}^{-3}$ on PDs when assuming a metastable state (Fig. 6a). Calculated $I_{\mathrm{s}}$ was similar for stable and metastable assumptions, ranging from 11.3 to $51.6 \mathrm{M}$ (Fig. 6b). The high $I_{\mathrm{S}}$ suggested aerosol water was nonideal and thus the influence of $I_{\mathrm{S}}$ on reaction rate constants (Table S3) and effective Henry's law constants (Table S5) was taken into consideration when the influence was known. The bulk aerosol $\mathrm{pH}$ predicted in stable state was in the range of 7.5 to 7.8 with a mean of $7.6 \pm 0.1$, consistent with bulk aerosol $\mathrm{pH}=7.63 \pm 0.03$ calculations during a haze event in Beijing 2015 predicted by Wang et al. (2016). The bulk aerosol $\mathrm{pH}$ calculated assuming metastable state was in the range of 3.4 to 7.6 with a mean of $4.7 \pm 1.1$, consistent with the mean value of 4.2 calculated in metastable aerosol assumption during severe haze in Beijing 2015-2016 by Liu et al. (2017). The calculated aerosol $\mathrm{pH}$ assuming metastable state decreased with increasing $\mathrm{PM}_{2.5}$ levels, from a mean of $6.5 \pm 1.3$ on NPDs to $4.4 \pm 0.6$ on PDs, while that assuming stable state shows no relationship with $\mathrm{PM}_{2.5}$ concentrations 


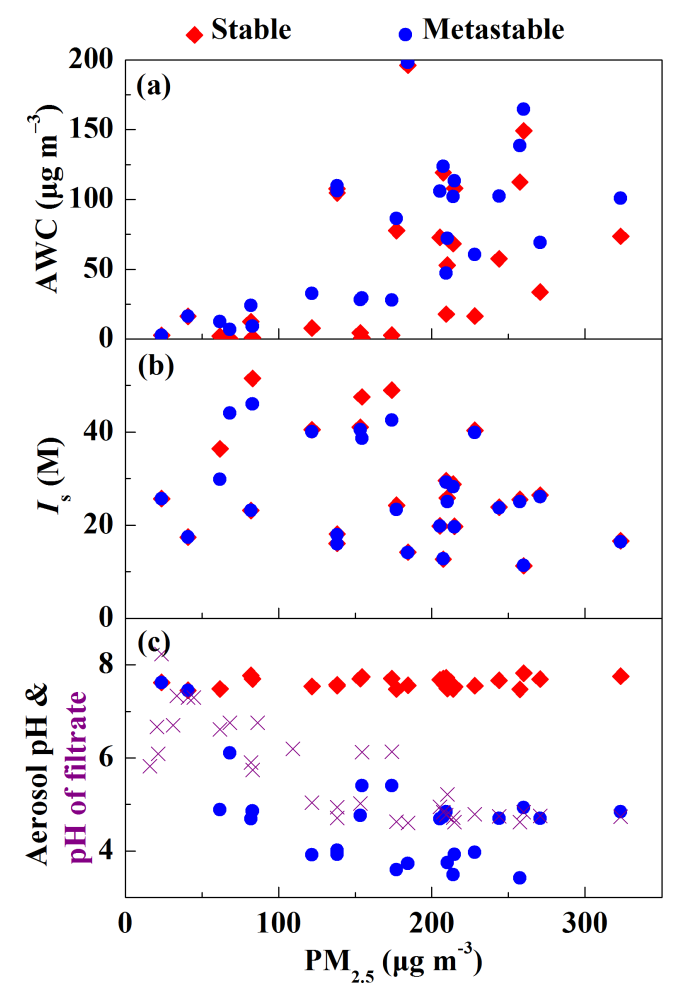

Figure 6. Aerosol parameters during Beijing haze. The aerosol liquid water content (AWC, a), ionic strength $\left(I_{\mathrm{S}}, \mathbf{b}\right)$, and aerosol $\mathrm{pH}$ (c) was predicted by ISORROPIA II assuming stable aerosol state and metastable aerosol state. The $\mathrm{pH}$ of filtrate was measured using an ion activity meter.

(Fig. 6c). Our measured $\mathrm{pH}$ of filtrate ranged from 4.6 to 8.2 with a mean of $5.7 \pm 1.0$, similar to $\mathrm{pH}$ of filtrate from $\mathrm{PM}_{2.5}$ in Beijing reported by Wang et al. (2005). The measured $\mathrm{pH}$ of filtrate shows similar trends with bulk aerosol $\mathrm{pH}$ calculated assuming metastable state (Fig. 6c), with a mean value $6.9 \pm 0.7$ on NPDs and $5.1 \pm 0.6$ on PDs, which suggests that bulk aerosols are in metastable state with moderate acidity on PDs. This is also consistent with our estimate that most aerosols are in a metastable state with a fraction of (74 \pm 17$) \%$ on PDs by using Eq. (9) and our cognition that the mixture of major acidic aerosols with minor neutral aerosols would lead to the bulk being acidic. However, as the effective Henry's law constant of $\mathrm{SO}_{2}$ at $\mathrm{pH}=7.6$ (stable state) can be 3 orders of magnitude higher than that at $\mathrm{pH}=4.4$ (metastable state on PDs), even a small fraction of aerosol at this high $\mathrm{pH}$ value could be potentially significant active sites for heterogeneous sulfate production during PDs.

The main heterogeneous sulfate formation pathways considered include $\mathrm{S}\left(\mathrm{IV}\right.$ ) oxidation by $\mathrm{H}_{2} \mathrm{O}_{2}, \mathrm{O}_{3}, \mathrm{NO}_{2}$, and $\mathrm{O}_{2}$ on acidic microdroplets as proposed by Hung and Hoffmann (2015). Other sulfate formation pathways such as S(IV) oxidation by $\mathrm{NO}_{3}$ radical, methyl-hydrogen peroxide (MHP), peroxyacetic acid (PAA), and hypohalous acids in aerosol water (Feingold et al., 2002; Walcek and Taylor, 1986; Chen et al., 2017) are thought to be negligible during haze in the NCP (Cheng et al., 2016), and thus are not considered here. We estimate the relative importance of these heterogeneous sulfate formation pathways as follows. First, the heterogeneous sulfate production rate via S(IV) oxidation by $\mathrm{H}_{2} \mathrm{O}_{2}\left(P_{\text {het, }} \mathrm{S}(\mathrm{IV})+\mathrm{H}_{2} \mathrm{O}_{2}\right)$ was calculated with the influence of $I_{\mathrm{s}}$ being considered, which has been determined at high $I_{\mathrm{S}}$ in laboratories (Tables S3 and S5). Then, the fractional contribution of $\mathrm{H}_{2} \mathrm{O}_{2}$ oxidation $\left(f_{\text {het, }} \mathrm{S}(\mathrm{IV})+\mathrm{H}_{2} \mathrm{O}_{2}\right)$ to overall heterogeneous sulfate production $\left(P_{\text {het }}\right)$ calculated using apparent $\gamma$ (see Sect. 2.3) was estimated. Large uncertainties exist in the influence of $I_{\mathrm{S}}$ on the reaction rate constant of $\mathrm{S}(\mathrm{IV})$ oxidation by $\mathrm{O}_{3}$ in aerosol water (Table S3), rendering the estimate of its fractional contribution $\left(f_{\text {het, }} \mathrm{S}(\mathrm{IV})+\mathrm{O}_{3}\right)$ to $P_{\text {het }}$ from purely chemical kinetic calculations uncertain. Instead, $f_{\text {het, }} \mathrm{S}(\mathrm{IV})+\mathrm{O}_{3}$ was estimated using our calculated $f_{\text {het, }} \mathrm{S}(\mathrm{IV})+\mathrm{H}_{2} \mathrm{O}_{2}$ and $\Delta^{17} \mathrm{O}_{\text {het }}$ values, on the basis that $\Delta^{17} \mathrm{O}\left(\mathrm{SO}_{4}^{2-}\right)>0 \%$ originates solely from $\mathrm{H}_{2} \mathrm{O}_{2}$ and $\mathrm{O}_{3}$ oxidation. Then zero- $\Delta{ }^{17} \mathrm{O}$ pathways such as $\mathrm{S}(\mathrm{IV})$ oxidation by $\mathrm{NO}_{2}$ and by $\mathrm{O}_{2}$ were estimated to be the remaining part $\left(f_{\text {het, zero }-\Delta^{17} \mathrm{O}}\right)$. At last, the potential importance of $\mathrm{S}(\mathrm{IV})$ oxidation by $\mathrm{NO}_{2}$ and by $\mathrm{O}_{2}$ is discussed.

Calculations show that $f_{\text {het, }} \mathrm{S}(\mathrm{IV})+\mathrm{H}_{2} \mathrm{O}_{2}$ was $4-6 \%$ with a mean of $(5 \pm 1) \%$ under stable aerosol assumptions and $8-19 \%$ with a mean of $(13 \pm 4) \%$ under metastablestate assumptions for PDs of all the cases. $f_{\text {het, }} \mathrm{S}(\mathrm{IV})+\mathrm{O}_{3}$ was calculated to be $2-47 \%$ with a mean of $(22 \pm 17) \%$ in stable-state assumption and $0-47 \%$ with a mean of $(21 \pm 18) \%$ in metastable-state assumption. Correspondingly, $f_{\text {het, zero }-\Delta{ }^{17} \mathrm{O}}$ was the remaining $73 \%(47-94 \%)$ in stable assumption, or $66 \%$ (42-81\%) in metastable assumption for PDs of all the cases (Fig. 7). Excluding PD of Case II, in which sulfate formation was predominated by in-cloud reactions, our local atmospheric-conditions-based calculations suggest zero- $\Delta{ }^{17} \mathrm{O}$ pathways such as $\mathrm{S}(\mathrm{IV})$ oxidation by $\mathrm{NO}_{2}$ and/or by $\mathrm{O}_{2}$ are important for sulfate formation during Beijing haze.

Cheng et al. (2016) suggested that $\mathrm{S}(\mathrm{IV})$ oxidation by $\mathrm{NO}_{2}$ in aerosol water could largely account for the missing sulfate source in 2013 Beijing haze. In their study, the calculated mean aerosol $\mathrm{pH}$ is 5.8, while influence of $I_{\mathrm{S}}$ was not taken into account due to the lack of relevant experimental data. The calculated $P_{\text {het, }} \mathrm{S}(\mathrm{IV})+\mathrm{NO}_{2}$ is highly sensitive to aerosol $\mathrm{pH}$. In our study, when aerosol $\mathrm{pH}$ decreased from $7.6 \pm 0.1$ assuming a stable state to $4.7 \pm 1.1$ assuming a metastable state, mean $P_{\text {het, }} \mathrm{S}(\mathrm{IV})+\mathrm{NO}_{2}$ decreased from $(6.5 \pm 7.7) \mu \mathrm{g} \mathrm{m}^{-3} \mathrm{~h}^{-1}$ to $(0.01 \pm 0.02) \mu \mathrm{g} \mathrm{m}^{-3} \mathrm{~h}^{-1}$ for PDs of all the cases (Fig. 7). The former is much larger than our estimate of overall heterogeneous production rate, $P_{\text {het }}=$ $(2.0 \pm 1.1) \mu \mathrm{g} \mathrm{m}^{-3} \mathrm{~h}^{-1}$, while the latter is too small. Moreover, the influence of $I_{\mathrm{S}}$ was not considered, which is expected to increase the reaction rate constant of S(IV) oxidation by $\mathrm{NO}_{2}$ (Cheng et al., 2016). The treatment of aerosols as a bulk quantity, assuming that all aerosols are either in stable or metastable state, or that all aerosol particles have the 


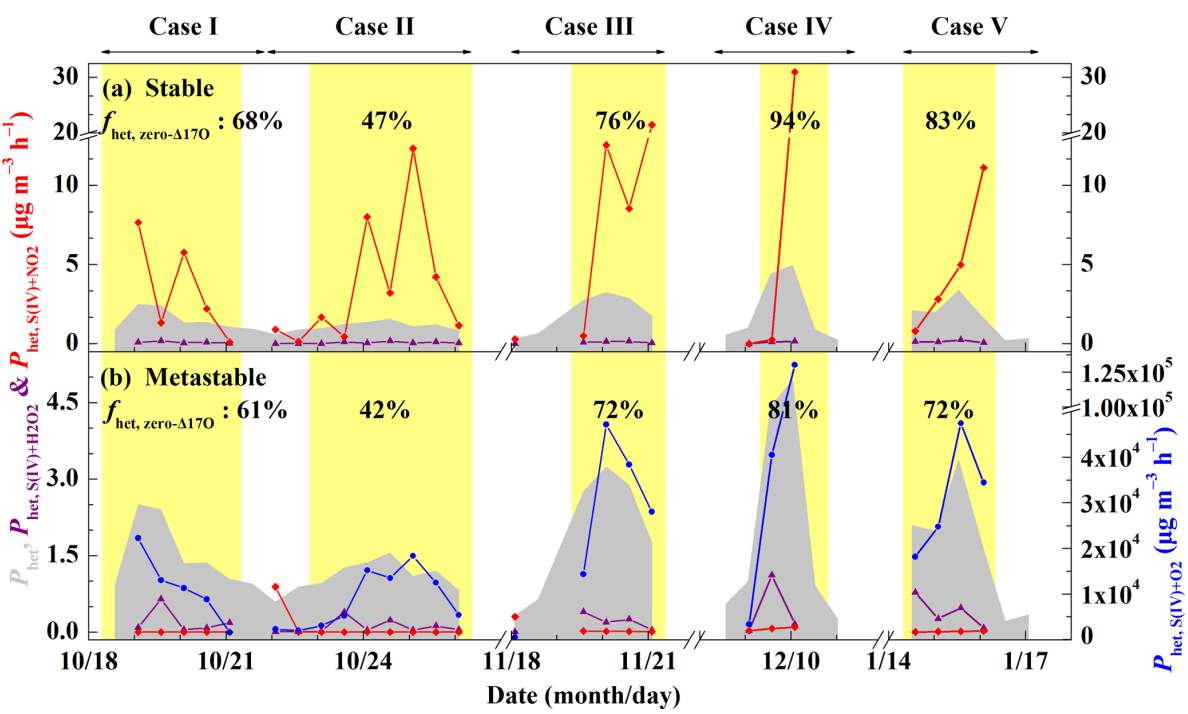

Figure 7. Estimate of heterogeneous sulfate production pathways. Time series of overall heterogeneous sulfate production rate $\left(P_{\text {het }}\right)$ and heterogeneous sulfate production rate in aerosol water via $\mathrm{H}_{2} \mathrm{O}_{2}\left(P_{\text {het, }} \mathrm{S}(\mathrm{IV})+\mathrm{H}_{2} \mathrm{O}_{2}\right)$ and $\mathrm{NO}_{2}\left(P_{\text {het, }} \mathrm{S}(\mathrm{IV})+\mathrm{NO}_{2}\right)$ under stable $($ a) and metastable (b) aerosol assumption. $P_{\text {het, }} \mathrm{S}(\mathrm{IV})+\mathrm{O}_{2}$ in (b) represents heterogeneous sulfate production rate via $\mathrm{SO}_{2}$ oxidation by $\mathrm{O}_{2}$ via a radical chain mechanism on acidic microdroplets. $f_{\text {het, zero }-\Delta{ }^{17} \mathrm{O}}$ represents the fraction of heterogeneous reactions that result in sulfate with zero- $\Delta^{17} \mathrm{O}$, such as $\mathrm{S}(\mathrm{IV})$ oxidation by $\mathrm{NO}_{2}$ and $\mathrm{O}_{2}$, to the overall heterogeneous sulfate production during PDs of each case with the constraint of $\Delta^{17} \mathrm{O}\left(\mathrm{SO}_{4}^{2-}\right)$ (see the main text for details). In calculating $P_{\text {het, }} \mathrm{S}(\mathrm{IV})+\mathrm{H}_{2} \mathrm{O}_{2}$, the influence of $I_{\mathrm{S}}$ was considered. In calculating $P_{\text {het, }}$ (IV) $+\mathrm{NO}_{2}$ and $P_{\text {het, }} \mathrm{S}(\mathrm{IV})+\mathrm{O}_{2}$ the influence of $I_{\mathrm{S}}$ was not considered due to the lack of experimental data about the influence of $I_{\mathrm{S}}$. $P_{\text {het, }}$ (IV) $+\mathrm{O}_{2}$ was calculated using the aqueous-phase rate constant for $\mathrm{pH} \leq 3$ due to the lack of rate constant information at $\mathrm{pH}>3$. The light yellow shaded area indicates polluted days (PDs, $\mathrm{PM}_{2.5} \geq 75 \mu \mathrm{g} \mathrm{m}^{-3}$ ). Data used here are 12-hourly averaged values, corresponding with filter samples.
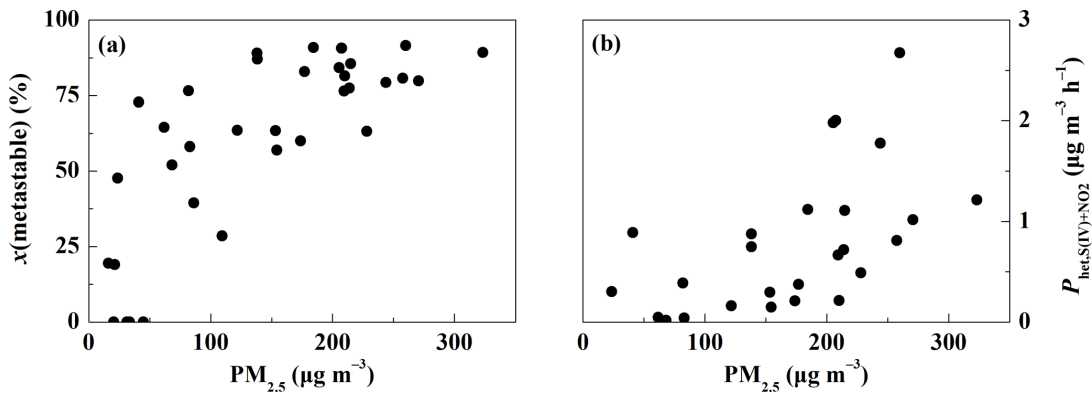

Figure 8. The estimated fraction of metastable aerosol to total aerosol ( $x$ (metastable), a) using Eq. (9) and heterogeneous sulfate production rate from $\mathrm{S}(\mathrm{IV})$ oxidation by $\mathrm{NO}_{2}$ assuming a combination of metastable and stable states $\left(P_{\text {het, }} \mathrm{S}(\mathrm{IV})+\mathrm{NO}_{2}, \mathbf{b}\right)$ as $P_{\text {het, }} \mathrm{S}(\mathrm{IV})+\mathrm{NO}_{2}=$ $x$ (metastable $) \times P_{\text {het, }} \mathrm{S}(\mathrm{IV})+\mathrm{NO}_{2}$, metastable $+(100 \%-x($ metastable $)) \times P_{\text {het, }} \mathrm{S}(\mathrm{IV})+\mathrm{NO}_{2}$, stable.

same $\mathrm{pH}$, may lead to errors in calculating heterogeneous sulfate production rates. As stated in Sect. 2.8, not all aerosols are in a metastable state, even though the fractional occurrence of metastable aerosols increases with increasing relative humidity (Rood et al., 1989). Figure 8a shows that the fraction of metastable aerosols to total aerosols, estimated by using Eq. (9), increases with $\mathrm{PM}_{2.5}$ levels. However, when assuming a combination of stable- and metastable-state aerosol as shown in Eq. (9), $P_{\text {het, }} \mathrm{S}(\mathrm{IV})+\mathrm{NO}_{2}$ increases with $\mathrm{PM}_{2.5}$ levels and reaches $(0.9 \pm 0.7) \mu \mathrm{g} \mathrm{m}^{-3} \mathrm{~h}^{-1}$ during PDs

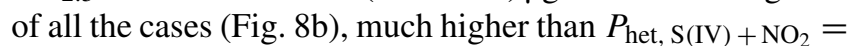

$(0.01 \pm 0.02) \mu \mathrm{g} \mathrm{m}^{-3} \mathrm{~h}^{-1}$ under solely metastable aerosol assumption. This estimate suggests that even though the majority of aerosols may be in a metastable state during PDs (74 $\pm 17 \%$ in our calculation), the high $\mathrm{pH}$ of the minority of aerosols in a stable state could render S(IV) oxidation by $\mathrm{NO}_{2}$ a potentially significant pathway for heterogeneous sulfate production.

Since $P_{\text {het, }} \mathrm{S}(\mathrm{IV})+\mathrm{NO}_{2}$ using calculated aerosol $\mathrm{pH}$ assuming metastable state was 2 orders of magnitude lower than $P_{\text {het }}$ during PDs, we further examined $\mathrm{S}(\mathrm{IV})$ oxidation by $\mathrm{O}_{2}$ on acidic microdroplets under the metastable-state assump- 
tion. A laboratory study suggested that $\mathrm{SO}_{2}$ oxidation by $\mathrm{O}_{2}$ on acidic microdroplets has a large aqueous-phase reaction rate constant of $1.5 \times 10^{6}[\mathrm{~S}(\mathrm{IV})]\left(\mathrm{M} \mathrm{s}^{-1}\right)$ at $\mathrm{pH} \leq 3$, a $\mathrm{pH}$ range much lower than our calculated $\mathrm{pH}$ values. The rate constant was shown to decrease with increasing $\mathrm{pH}$; however, no values of the rate constant at $\mathrm{pH}>3$ were reported (Hung and Hoffmann, 2015). Figure 7b shows heterogenous sulfate production rate via $\mathrm{S}(\mathrm{IV})$ oxidation by $\mathrm{O}_{2}$ on acidic microdroplets $\left(P_{\text {het, }} \mathrm{S}(\mathrm{IV})+\mathrm{O}_{2}\right)$ with aerosol liquid water content calculated assuming metastable state and the aqueousphase rate constant for $\mathrm{pH} \leq 3$ being used, even though the calculated aerosol $\mathrm{pH}$ is $>3$. The estimated $P_{\text {het, }} \mathrm{S}(\mathrm{IV})+\mathrm{O}_{2}$ is $1.5 \times 10^{3}$ to $1.3 \times 10^{5} \mathrm{\mu g} \mathrm{m}^{-3} \mathrm{~h}^{-1}$ with a mean of $2.5 \times$ $10^{4} \mu \mathrm{g} \mathrm{m}^{-3} \mathrm{~h}^{-1}$ during PDs of all cases, which is 4 orders of magnitude larger than $P_{\text {het }}$. This value should be an overestimate due to our calculated bulk aerosol $\mathrm{pH}$ predicted in a metastable state being $4.4 \pm 0.6$ during PDs and the experimental results of He et al. (2014) and Wang et al. (2016) suggest the $\mathrm{O}_{2}$ oxidation pathway is negligible at higher $\mathrm{pH}$ conditions (e.g., on $\mathrm{CaO}$ and in $\mathrm{NH}_{4}^{+}$solution). However, some fraction of aerosols may have a $\mathrm{pH} \leq 3$ due to the Kelvin effect (Hung and Hoffmann, 2015), rendering S(IV) oxidation by $\mathrm{O}_{2}$ on acidic microdroplets a potentially important pathway for heterogeneous sulfate production even if it may occur on only a small fraction of the ambient aerosol.

\section{Conclusions}

Our study suggests that both in-cloud reactions and heterogeneous reactions can dominate sulfate formation during Beijing haze, with the fractional contribution of $f_{\text {cloud }}=68 \%$ in Case II and $f_{\text {het }}=(48 \pm 5) \%$ in Cases I and III-V. The $\Delta^{17} \mathrm{O}$-constrained calculation shows that the heterogeneous sulfate production during haze events in our observation was mainly (66 to $73 \%$ on average) from reactions that result in sulfate with $\Delta^{17} \mathrm{O}=0 \%$, e.g., $\mathrm{S}(\mathrm{IV})$ oxidation by $\mathrm{NO}_{2}$ and/or by $\mathrm{O}_{2}$. $\mathrm{S}(\mathrm{IV})$ oxidation by $\mathrm{H}_{2} \mathrm{O}_{2}$ and $\mathrm{O}_{3}$ accounted for the rest ( 27 to $34 \%$ ) of heterogeneous sulfate production. However, given the large difference in predicted aerosol $\mathrm{pH}$ assuming metastable aerosol state and stable aerosol state $(\mathrm{pH}=7.6 \pm 0.1$ and $4.7 \pm 1.1$, respectively) and the strong dependence of $\mathrm{SO}_{2}$ oxidation on aerosol $\mathrm{pH}$, we cannot quantify the relative importance of these two pathways for heterogeneous sulfate production. $\mathrm{S}(\mathrm{IV})+\mathrm{NO}_{2}$ can be the dominant pathway when aerosols are in stable state with $\mathrm{pH}=7.6 \pm 0.1$, while $\mathrm{S}(\mathrm{IV})+\mathrm{O}_{2}$ can take over providing that highly acidic aerosols $(\mathrm{pH} \leq 3)$ exist. To distinguish which of these two mechanisms is more important for sulfate formation during Beijing haze, the heterogeneity of aerosol state and $\mathrm{pH}$ should be considered in future studies.

Data availability. All data needed to draw the conclusions in the present study are shown in this paper and/or the Supplement. For additional data related to this study, please contact the corresponding author (zqxie@ustc.edu.cn).

\section{The Supplement related to this article is available online at https://doi.org/10.5194/acp-18-5515-2018-supplement.}

Author contributions. ZQX conceived the study. PZH conducted oxygen isotope measurements supervised by BA and LG. PZH, XYC, SDF, HCZ, and HK performed the field experiments and aerosol chemical composition measurements. PZH, BA, ZQX, LG, HS, and YFC interpreted the data. HS, YFC, and GJZ were involved in the discussion of oxidation pathway calculation. CL contributed to the field observation support. PZH wrote the paper with input from BA, ZQX, and LG. All authors were involved in the discussion and revision.

Competing interests. The authors declare that they have no conflict of interest.

Acknowledgements. We thank Andrew J. Schauer and Qianjie Chen at the University of Washington for help with isotope ratio measurements. Zhouqing Xie acknowledges support from the National Key Project of MOST (2016YFC0203302), NSFC (91544013), Key Project of CAS (KJZD-EW-TZ-G06-01), and Atmospheric Pollution Control of the Prime Minister (DQGG0104). Becky Alexander acknowledges support from NSF AGS 1644998. Hang Su acknowledges support from the National Key Project of MOST (2017YFC0210104) and NSFC (91644218).

Edited by: Jan Kaiser

Reviewed by: Mang Lin and two anonymous referees

\section{References}

Alexander, B., Park, R. J., Jacob, D. J., Li, Q., Yantosca, R. M., Savarino, J., Lee, C., and Thiemens, M.: Sulfate formation in sea-salt aerosols: Constraints from oxygen isotopes, J. Geophys. Res., 110, D10307, https://doi.org/10.1029/2004JD005659, 2005.

Alexander, B., Park, R. J., Jacob, D. J., and Gong, S.: Transition metal-catalyzed oxidation of atmospheric sulfur: Global implications for the sulfur budget, J. Geophys. Res., 114, D02309, https://doi.org/10.1029/2008JD010486, 2009.

Alexander, B., Allman, D., Amos, H., Fairlie, T., Dachs, J., Hegg, D. A., and Sletten, R. S.: Isotopic constraints on the formation pathways of sulfate aerosol in the marine boundary layer of the subtropical northeast Atlantic Ocean, J. Geophys. Res., 117, D06304, https://doi.org/10.1029/2011JD016773, 2012.

Bao, H., Thiemens, M. H., Farquhar, J., Campbell, D. A., Lee, C. C.W., Heine, K., and Loope, D. B.: Anomalous ${ }^{17} \mathrm{O}$ compositions in massive sulphate deposits on the Earth, Nature, 406, 176-178, 2000.

Bian, Y. X., Zhao, C. S., Ma, N., Chen, J., and Xu, W. Y.: A study of aerosol liquid water content based on hygroscopicity measure- 
ments at high relative humidity in the North China Plain, Atmos. Chem. Phys., 14, 6417-6426, https://doi.org/10.5194/acp14-6417-2014, 2014.

Brook, R. D., Rajagopalan, S., Pope, C. A., Brook, J. R., Bhatnagar, A., Diez-Roux, A. V., Holguin, F., Hong, Y., Luepker, R. V., and Mittleman, M. A.: Particulate matter air pollution and cardiovascular disease an update to the scientific statement from the American Heart Association, Circulation, 121, 2331-2378, 2010.

Calhoun, J. A., Bates, T. S., and Charlson, R. J.: Sulfur isotope measurements of submicrometer sulfate aerosol particles over the $\mathrm{Pa}$ cific Ocean, Geophys. Res. Lett., 18, 1877-1880, 1991.

Chen, Q., Geng, L., Schmidt, J. A., Xie, Z., Kang, H., Dachs, J., Cole-Dai, J., Schauer, A. J., Camp, M. G., and Alexander, B.: Isotopic constraints on the role of hypohalous acids in sulfate aerosol formation in the remote marine boundary layer, Atmos. Chem. Phys., 16, 11433-11450, https://doi.org/10.5194/acp-1611433-2016, 2016.

Chen, Q., Schmidt, J. A., Shah, V., Jaeglé, L., Sherwen, T., and Alexander, B.: Sulfate production by reactive bromine: Implications for the global sulfur and reactive bromine budgets, Geophys. Res. Lett., 44, 7069-7078, 2017.

Cheng, Y., Zheng, G., Wei, C., Mu, Q., Zheng, B., Wang, Z., Gao, M., Zhang, Q., He, K., and Carmichael, G.: Reactive nitrogen chemistry in aerosol water as a source of sulfate during haze events in China, Science Advances, 2, e1601530, https://doi.org/10.1126/sciadv.1601530, 2016.

Cheng, Z., Jiang, J., Fajardo, O., Wang, S., and Hao, J.: Characteristics and health impacts of particulate matter pollution in China (2001-2011), Atmos. Environ., 65, 186-194, 2013.

Clifton, C. L., Altstein, N., and Huie, R. E.: Rate constant for the reaction of nitrogen dioxide with sulfur (IV) over the $\mathrm{pH}$ range 5.3-13, Environ. Sci. Technol., 22, 586-589, 1988.

Dubey, M. K., Mohrschladt, R., Donahue, N. M., and Anderson, J. G.: Isotope specific kinetics of hydroxyl radical $(\mathrm{OH})$ with water $\left(\mathrm{H}_{2} \mathrm{O}\right)$ : Testing models of reactivity and atmospheric fractionation, J. Phys. Chem. A, 101, 1494-1500, 1997.

Faloona, I.: Sulfur processing in the marine atmospheric boundary layer: A review and critical assessment of modeling uncertainties, Atmos. Environ., 43, 2841-2854, 2009.

Feingold, G., Frost, G. J., and Ravishankara, A.: Role of $\mathrm{NO}_{3}$ in sulfate production in the wintertime northern latitudes, J. Geophys. Res., 107, 4640, https://doi.org/10.1029/2002JD002288, 2002.

Fountoukis, C. and Nenes, A.: ISORROPIA II: a computationally efficient thermodynamic equilibrium model for $\mathrm{K}^{+}-$ $\mathrm{Ca}^{2+}-\mathrm{Mg}^{2+}-\mathrm{NH}_{4}^{+}-\mathrm{Na}^{+}-\mathrm{SO}_{4}^{2-}-\mathrm{NO}_{3}^{-}-\mathrm{Cl}^{-}-\mathrm{H}_{2} \mathrm{O}$ aerosols, Atmos. Chem. Phys., 7, 4639-4659, https://doi.org/10.5194/acp-74639-2007, 2007.

$\mathrm{Fu}, \mathrm{A} .:$ Study on peroxides concentration and its influencing factors in the urban atmosphere, master of engineering, College of Environmental and Resource Sciences, Zhejiang University, Hangzhou, China, 56 pp., 2014 (in Chinese).

Geng, L., Schauer, A. J., Kunasek, S. A., Sofen, E. D., Erbland, J., Savarino, J., Allman, D. J., Sletten, R. S., and Alexander, B.: Analysis of oxygen-17 excess of nitrate and sulfate at submicromole levels using the pyrolysis method, Rapid Commun. Mass Sp., 27, 2411-2419, 2013.

Guo, H., Weber, R. J., and Nenes, A.: High levels of ammonia do not raise fine particle $\mathrm{pH}$ sufficiently to yield nitro- gen oxide-dominated sulfate production, Sci. Rep., 7, 12109, https://doi.org/10.1038/s41598-017-11704-0, 2017.

Guo, J., Wang, Y., Shen, X., Wang, Z., Lee, T., Wang, X., Li, P., Sun, M., Collett, J. L., and Wang, W.: Characterization of cloud water chemistry at Mount Tai, China: Seasonal variation, anthropogenic impact, and cloud processing, Atmos. Environ., 60, 467476, 2012.

Guo, S., Hu, M., Zamora, M. L., Peng, J., Shang, D., Zheng, J., Du, Z., Wu, Z., Shao, M., and Zeng, L.: Elucidating severe urban haze formation in China, P. Natl. Acad. Sci. USA, 111, 17373-17378, 2014.

Harris, E., Sinha, B., van Pinxteren, D., Tilgner, A., Fomba, K. W., Schneider, J., Roth, A., Gnauk, T., Fahlbusch, B., Mertes, S., Lee, T., Collett, J., Foley, S., Borrmann, S., Hoppe, P., and Herrmann, H.: Enhanced Role of Transition Metal Ion Catalysis During InCloud Oxidation of $\mathrm{SO}_{2}$, Science, 340, 727-730, 2013.

He, H., Wang, Y., Ma, Q., Ma, J., Chu, B., Ji, D., Tang, G., Liu, C., Zhang, H., and Hao, J.: Mineral dust and NOx promote the conversion of $\mathrm{SO}_{2}$ to sulfate in heavy pollution days, Sci. Rep., 4, 4172, https://doi.org/10.1038/srep04172, 2014.

Hennigan, C. J., Izumi, J., Sullivan, A. P., Weber, R. J., and Nenes, A.: A critical evaluation of proxy methods used to estimate the acidity of atmospheric particles, Atmos. Chem. Phys., 15, 27752790, https://doi.org/10.5194/acp-15-2775-2015, 2015.

Hoffmann, M. R. and Calvert, J. G.: Chemical Transformation Modules for Eulerian Acid Deposition Models: Volume II, the Aqueous-phase Chemistry, Atmospheric Sciences Research Laboratory, Office of Research and Development, US Environmental Protection Agency, 1985.

Holt, B., Kumar, R., and Cunningham, P.: Oxygen-18 study of the aqueous-phase oxidation of sulfur dioxide, Atmos. Environ., 15, 557-566, 1981.

Hung, H.-M. and Hoffmann, M. R.: Oxidation of gas-Phase $\mathrm{SO}_{2}$ on the surfaces of acidic microdroplets: Implications for sulfate and sulfate radical anion formation in the atmospheric liquid phase, Environ. Sci. Technol., 49, 13768-13776, 2015.

Ibusuki, T. and Takeuchi, K.: Sulfur dioxide oxidation by oxygen catalyzed by mixtures of manganese (II) and iron (III) in aqueous solutions at environmental reaction conditions, Atmos. Environ., 21, 1555-1560, 1987.

Ishino, S., Hattori, S., Savarino, J., Jourdain, B., Preunkert, S., Legrand, M., Caillon, N., Barbero, A., Kuribayashi, K., and Yoshida, N.: Seasonal variations of triple oxygen isotopic compositions of atmospheric sulfate, nitrate, and ozone at Dumont d'Urville, coastal Antarctica, Atmos. Chem. Phys., 17, 37133727, https://doi.org/10.5194/acp-17-3713-2017, 2017.

Jacob, D. J.: Heterogeneous chemistry and tropospheric ozone, Atmos. Environ., 34, 2131-2159, 2000.

Jenkins, K. A. and Bao, H.: Multiple oxygen and sulfur isotope compositions of atmospheric sulfate in Baton Rouge, LA, USA, Atmos. Environ., 40, 4528-4537, 2006.

Jiang, J., Zhou, W., Cheng, Z., Wang, S., He, K., and Hao, J.: Particulate matter distributions in China during a winter period with frequent pollution episodes (January 2013), Aerosol Air Qual. Res., 15, 494-503, 2015.

Lee, C. W., Savarino, J., Cachier, H., and Thiemens, M.: Sulfur $\left({ }^{32} \mathrm{~S},{ }^{33} \mathrm{~S},{ }^{34} \mathrm{~S},{ }^{36} \mathrm{~S}\right)$ and oxygen $\left({ }^{16} \mathrm{O},{ }^{17} \mathrm{O},{ }^{18} \mathrm{O}\right)$ isotopic ratios of primary sulfate produced from combustion processes, Tellus B, 54, 193-200, 2002. 
Lee, Y. N. and Schwartz, S. E.: Kinetics of oxidation of aqueous sulfur (IV) by nitrogen dioxide, in: Kinetics of oxidation of aqueous sulfur (IV) by nitrogen dioxide, Precipitation scavenging, dry Deposition and resuspension, Santa Monica, CA, USA, 29 Novemebr 1982, 453-470, 1983.

Legrand, M., Hammer, C., De Angelis, M., Savarino, J., Delmas, R., Clausen, H., and Johnsen, S. J.: Sulfur-containing species (methanesulfonate and $\mathrm{SO}_{4}$ ) over the last climatic cycle in the Greenland Ice Core Project (central Greenland) ice core, J. Geophys. Res., 102, 26663-26679, 1997.

Legrand, M. and Mayewski, P.: Glaciochemistry of polar ice cores: A review, Rev. Geophys., 35, 219-243, 1997.

Li, L., Chen, Z. M., Zhang, Y. H., Zhu, T., Li, J. L., and Ding, J.: Kinetics and mechanism of heterogeneous oxidation of sulfur dioxide by ozone on surface of calcium carbonate, Atmos. Chem. Phys., 6, 2453-2464, https://doi.org/10.5194/acp-6-24532006, 2006.

Li, X., Bao, H., Gan, Y., Zhou, A., and Liu, Y.: Multiple oxygen and sulfur isotope compositions of secondary atmospheric sulfate in a mega-city in central China, Atmos. Environ., 81, 591-599, 2013.

Lin, M., Biglari, S., Zhang, Z., Crocker, D., Tao, J., Su, B., Liu, L., and Thiemens, M. H.: Vertically uniform formation pathways of tropospheric sulfate aerosols in East China detected from triple stable oxygen and radiogenic sulfur isotopes, Geophys. Res. Lett., 44, 5187-5196, 2017.

Liu, M., Song, Y., Zhou, T., Xu, Z., Yan, C., Zheng, M., Wu, Z., Hu, M., Wu, Y., and Zhu, T.: Fine Particle pH during Severe Haze Episodes in Northern China, Geophys. Res. Lett., 44, 52135221, 2017.

Liu, X. and Millero, F. J.: The solubility of iron hydroxide in sodium chloride solutions, Geochim. Cosmochim. Ac., 63, 3487-3497, 1999.

Luz, B. and Barkan, E.: The isotopic ratios ${ }^{17} \mathrm{O} /{ }^{16} \mathrm{O}$ and ${ }^{18} \mathrm{O} /{ }^{16} \mathrm{O}$ in molecular oxygen and their significance in biogeochemistry, Geochim. Cosmochim. Ac., 69, 1099-1110, 2005.

Martin, L. R. and Hill, M. W.: The iron catalyzed oxidation of sulfur: Reconciliation of the literature rates, Atmos. Environ., 21, 1487-1490, 1967.

Matsuhisa, Y., Goldsmith, J. R., and Clayton, R. N.: Mechanisms of hydrothermal crystallization of quartz at $250{ }^{\circ} \mathrm{C}$ and $15 \mathrm{kbar}$, Geochim. Cosmochim. Ac., 42, 173-182, 1978.

McArdle, J. V. and Hoffmann, M. R.: Kinetics and mechanism of the oxidation of aquated sulfur dioxide by hydrogen peroxide at low pH, J. Phys. Chem., 87, 5425-5429, 1983.

Meng, Z. Y., Lin, W. L., Jiang, X. M., Yan, P., Wang, Y., Zhang, Y. M., Jia, X. F., and Yu, X. L.: Characteristics of atmospheric ammonia over Beijing, China, Atmos. Chem. Phys., 11, 61396151, https://doi.org/10.5194/acp-11-6139-2011, 2011.

Rood, M., Shaw, M., Larson, T., and Covert, D.: Ubiquitous nature of ambient metastable aerosol, Nature, 337, 537-539, 1989.

Savarino, J. and Thiemens, M. H.: Analytical procedure to determine both $\delta^{18} \mathrm{O}$ and $\delta^{17} \mathrm{O}$ of $\mathrm{H}_{2} \mathrm{O}_{2}$ in natural water and first measurements, Atmos. Environ., 33, 3683-3690, 1999.

Savarino, J., Lee, C. C., and Thiemens, M. H.: Laboratory oxygen isotopic study of sulfur (IV) oxidation: Origin of the massindependent oxygen isotopic anomaly in atmospheric sulfates and sulfate mineral deposits on Earth, J. Geophys. Res., 105, 29079-29088, 2000.
Savarino, J., Alexander, B., Darmohusodo, V., and Thiemens, M. H.: Sulfur and oxygen isotope analysis of sulfate at micromole levels using a pyrolysis technique in a continuous flow system, Anal. Chem., 73, 4457-4462, 2001.

Seinfeld, J. H. and Pandis, S. N.: Atmospheric chemistry and physics: From air pollution to climate change, John Wiley \& Sons, New Jersey, 2006.

Shen, C. H. and Rochelle, G. T.: Nitrogen dioxide absorption and sulfite oxidation in aqueous sulfite, Environ. Sci. Technol., 32, 1994-2003, 1998.

Shen, X., Lee, T., Guo, J., Wang, X., Li, P., Xu, P., Wang, Y., Ren, Y., Wang, W., and Wang, T.: Aqueous phase sulfate production in clouds in eastern China, Atmos. Environ., 62, 502-511, 2012.

Sofen, E. D., Alexander, B., Steig, E. J., Thiemens, M. H., Kunasek, S. A., Amos, H. M., Schauer, A. J., Hastings, M. G., Bautista, J., Jackson, T. L., Vogel, L. E., McConnell, J. R., Pasteris, D. R., and Saltzman, E. S.: WAIS Divide ice core suggests sustained changes in the atmospheric formation pathways of sulfate and nitrate since the 19th century in the extratropical Southern Hemisphere, Atmos. Chem. Phys., 14, 5749-5769, https://doi.org/10.5194/acp-14-5749-2014, 2014.

Sun, Y., Zhuang, G., Tang, A., Wang, Y., and An, Z.: Chemical characteristics of $\mathrm{PM}_{2.5}$ and $\mathrm{PM}_{10}$ in haze-fog episodes in Beijing, Environ. Sci. Technol., 40, 3148-3155, 2006.

Vicars, W. C. and Savarino, J.: Quantitative constraints on the ${ }^{17} \mathrm{O}$ excess $\left(\Delta^{17} \mathrm{O}\right)$ signature of surface ozone: Ambient measurements from $50^{\circ} \mathrm{N}$ to $50^{\circ} \mathrm{S}$ using the nitrite-coated filter technique, Geochim. Cosmochim. Ac., 135, 270-287, 2014.

Walcek, C. J. and Taylor, G. R.: A theoretical method for computing vertical distributions of acidity and sulfate production within cumulus clouds, J. Atmos. Sci., 43, 339-355, 1986.

Wang, G., Zhang, R., Gomez, M. E., Yang, L., Zamora, M. L., Hu, M., Lin, Y., Peng, J., Guo, S., and Meng, J.: Persistent sulfate formation from London Fog to Chinese haze, P. Natl. Acad. Sci. USA, 113, 13630-13635, 2016.

Wang, Y., Zhuang, G., Tang, A., Yuan, H., Sun, Y., Chen, S., and Zheng, A.: The ion chemistry and the source of $\mathrm{PM}_{2.5}$ aerosol in Beijing, Atmos. Environ., 39, 3771-3784, 2005.

Wang, Y., Zhang, Q., Jiang, J., Zhou, W., Wang, B., He, K., Duan, F., Zhang, Q., Philip, S., and Xie, Y.: Enhanced sulfate formation during China's severe winter haze episode in January 2013 missing from current models, J. Geophys. Res., 119, 10425-10440, 2014.

Ye, P., Xie, Z., Yu, J., and Kang, H.: Spatial distribution of methanesulphonic acid in the Arctic aerosol collected during the Chinese Arctic Research Expedition, Atmosphere, 6, 699-712, 2015.

Zheng, B., Zhang, Q., Zhang, Y., He, K. B., Wang, K., Zheng, G. J., Duan, F. K., Ma, Y. L., and Kimoto, T.: Heterogeneous chemistry: a mechanism missing in current models to explain secondary inorganic aerosol formation during the January 2013 haze episode in North China, Atmos. Chem. Phys., 15, 2031-2049, https://doi.org/10.5194/acp-15-2031-2015, 2015a.

Zheng, G. J., Duan, F. K., Su, H., Ma, Y. L., Cheng, Y., Zheng, B., Zhang, Q., Huang, T., Kimoto, T., Chang, D., Pöschl, U., Cheng, Y. F., and He, K. B.: Exploring the severe winter haze in Beijing: the impact of synoptic weather, regional transport and heterogeneous reactions, Atmos. Chem. Phys., 15, 2969-2983, https://doi.org/10.5194/acp-15-2969-2015, 2015 b. 